Bulletin No. 267

Series $\left\{\begin{array}{l}\text { A, Economic Geology, } 60 \\ \text { B, Descriptive Geology, } 70\end{array}\right.$

DEPARTMENT OF THE INTERIOR

UNITED STATES GEOLOGICAL SURVEY

CHARLES D. WALCOTT, DIRECTOR

\author{
T H E
}

\title{
COPPER DEPOSITS OF MISSOURI
}

BY

H. FÓSTER BAIN AND E. O. ULRICH

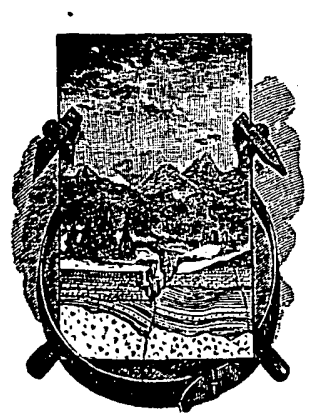

W ASHINGTON

GOVERNMENT PRINTING OFFICE

1905 
'

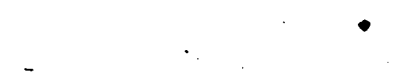

$\bullet$ 


\section{CONTENTS.}

Letter of transmittrol $\ldots \ldots \ldots \ldots \ldots$

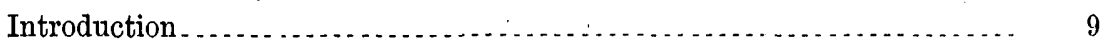

Scope oi this ręport $\ldots \ldots \ldots \ldots \ldots \ldots \ldots$

History $\ldots \ldots \ldots \ldots$

General distribution of the copper.................... 10

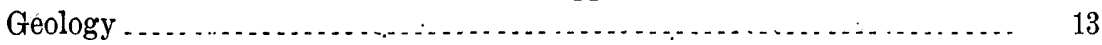

Former classifications of the rocks . ...

Swallow's scheme........................................ 13

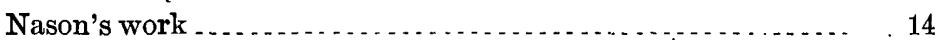

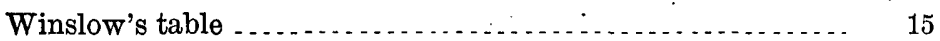

Keyes's report . . . . . . . . . . . . . . . . . 16

Nason's later discoveries $\ldots \ldots \ldots \ldots \ldots$

The Ball and Smith report . . . . . . . . . . . . . . . .

General remarks on the "Ozark series" of rocks. . ................. 19

Description of formations .................................. 20

La Motte sandstone . .

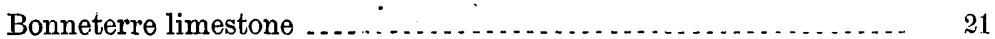

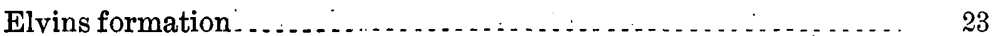

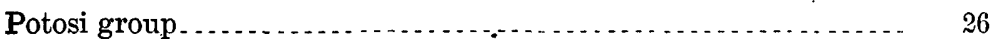

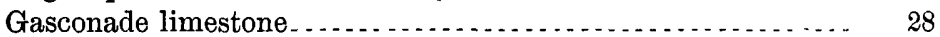

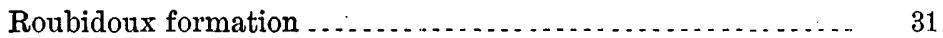

Jefferson City limestone .................................. 33

St. Peter ("Crystal City") sandstone ....................... 35

Joachim limestone ........................................ 36

The ore deposits $\ldots \ldots \ldots \ldots \ldots \ldots \ldots$

The Ste. Genevieve mines . . . . . . . . . . . . . . .

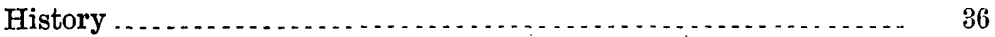

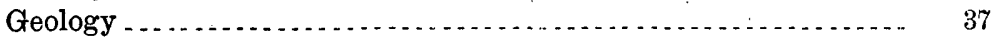

Ore bodies . . . .

Value of the deposits. . . . . . . .

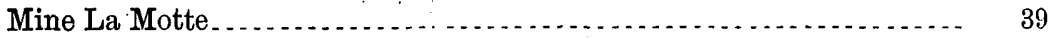

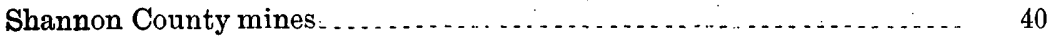

Location .................................................. 40

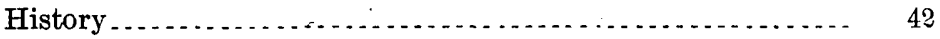

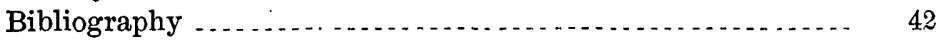

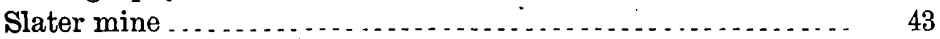

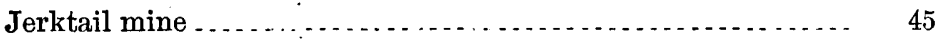

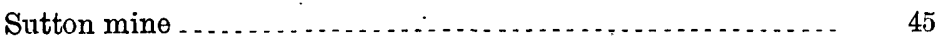

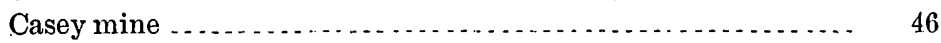

Tyrell mine . . . . . 
The ore deposits-Continued.

Page.

Shannon County mines-Continued.

Bonanza prospect $\ldots \ldots \ldots \ldots \ldots$

Freeman prospect.................................... 47

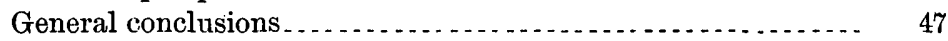

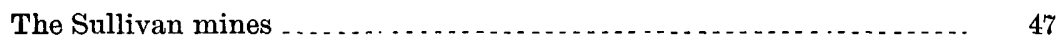

History $\ldots \ldots \ldots \ldots \ldots \ldots$

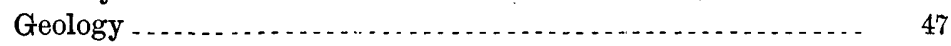

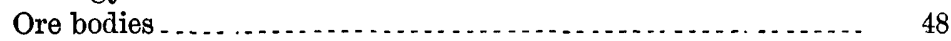

Value of the deposits . . . . . . . .

General summary and conclusions ............................... 50

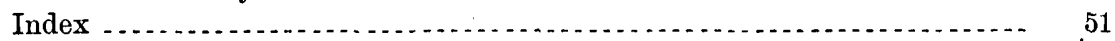




\section{L L U S T R A T I O N S.}

Page.

Plate I. The workings of the Cornwall mine, Ste. Genevieve County ...... 36

Fig. 1. Sketch map showing location of copper deposits ............. 11

2. Sketch map showing occurrences of copper in Shannon County .. 41 



\title{
LETTER OF TRANSMITTAL.
}

\author{
Departiment of the Interior, \\ United Stattes Geological Survey, \\ Washington, L. C., February 17,1 G1)5.
}

SIR: I submit herewith the manuscript of a report on the copper deposits of Missouri, by H. Foster Bain and E. O. Ulrich, and recommend its publication as a bulletin.

The report is the result of field work undertaken last season by. Messrs. Bain and Ulrich in response to numerous requests for information concerning the copper deposits of Missouri. It contains a summary of all available information regarding the copper deposits and a preliminary statement of the stratigraphy of the region in as great detail as the facts at hand warrant and as is necessary to a proper understanding of the occurrence and geological relations of the copper.

Very respectfully,

C. W. Hayes, Geologist in Charge of Geology.

Hon. Charles D. Walcott, Director United States Geological Survey. 


\title{
COPPER DEPOSITS OF MISSOURI.
}

\author{
By H. Foster Bain and E. O. Ulrich.
}

\section{INTRODUCTION.}

Scope of this report.-Copper is now being mined and smelted near Sullivan, Mo., and at other points in the State copper deposits are attracting attention. The present paper is a brief account of those deposits which have so far been mined, with such suggestions as seem warranted regarding further prospecting. The occurrence of copper in quantities permitting actual exploitation in the midst of a great area of unaltered and little disturbed sedimentary rocks raises many interesting questions of genesis. These, however, can not be adequately discussed until the general studies upon the lead, zinc, and other ores of the Mississippi Valley are somewhat further advanced.

The present paper is based upon work done in 1904 by the authors, assisted by E. E. Ellis. Mr. Bain is responsible for all statements relating to the ore deposits and mines, while $\mathrm{Mr}$. Ulrich has made the determinations of the geologic horizons and has written the description of the formations.

History.--Attempts to mine copper have been made in Missouri since 1837, and at different times copper furnaces have been operated in Shannon, Ste. Genevieve, and Crawford counties, while a matte carrying in addition nickel and cobalt has been steadily produced at Mine La Motte. These localities are shown on the accompanying sketch map (fig. 1,.p. 11). Copper has probably been shipped in small quantities from several other counties also. Shumard, ${ }^{a}$ writing in 1860, enumerated 15 counties in which copper was known to occur. Even at that he missed Ste. Genevieve, the one from which the main output has come. Very little attempt had then been made to develop the deposits. After the work of Joseph Slater in Shannon County in 1837 no serious effort to mine was made until 1876 , when Charles $T$. Biser shipped a few carloads from the same locality. About the same time the Ste. Genevieve mines were developed, and they continued in operation until about six years ago. In 1904 the furnace of

" Shumard, B. F., Report of progress: Missouri Geol. Survey, 1861, pp. 7-9. 
the Missouri Copper Mountain Mining Company, at Sullivan, was put in blast and metal began to be shipped to Chicago for refining.

There are no exact figures of the amount of copper so far produced. Ladd ${ }^{a}$ estimated the total as having been worth less than $\$ 20,000$. This is probably too low, since the Ste. Genevieve mines produced regularly for some years and in 1880 alone were credited by the Tenth Census with an output of $\$ 2 \tilde{5}, 730$. Local estimates of the production of the Slater mine, in Shannon County, indicated a production of approximately $\$ 50,000$. In 1903 the State mine inspector, G. K. Williams, is quoted ${ }^{b}$ as estimating the sales of copper ore for the year to amount to $\$ 30,210$. In 1904 the furnace at Sullivan shipped two carloads of metal, and for some years a copper matte has been regularly shipped from Mine La Motte: From this it appears that copper in important amounts has been actually marketed from this State for some years.

General distribution of the copper--Copper-bearing pyrites are widely distributed in Missouri, as in many other States, and the brilliant colors of the alteration products lead to ready recognition. Occurrences have been noted in Benton, Clark, Crawford, Dade, Dallas, Dent, Franklin, Greene, Iron, Jasper, Jefferson, Lawrence, Madison, Maries, St. Francois, Ste. Genevieve, Shannon, Washington, and probably a number of other counties. For the most part these occurrences may be at once dismissed as of no economic importance. The four which have yielded ore have already been noted.

With the exception of one or two sporadic occurrences of merely mineralogic interest, copper is found only in the southern part of Missouri, within the region broadly known as the Ozark uplift. This is an elliptical, warped plateau having a major northeast-southwest axis of some 300 miles and reaching its topographic culmination at Cedar Gap, somewhat west of the copper-bearing territory.

Its geologic center is to the east, where, in Iron, Madison, St. Francois, and adjacent counties, there exists a series of semidetached elevations made up of crystalline rocks, known as the "St. Francis Mountains." These rocks, mainly granite and porphyry, but with subordinate amounts of basic intrusives and probably of metamorphosed sediments, are of pre-Cambrian age. Around them in concentric belts, each wider to the west than the east, are the Cambrian, Ordovician, and later rocks, more especially described below. The region is one of important and varied mineral wealth. Iron, lead, zinc, barite, and manganese, as well as copper, occur and are mined. Despite the fact that it includes some of the earliest American settlements, considerable areas within it are very sparsely settled, are undeveloped, and, in comparison with the surrounding territory, are

$a$ Ladd, G. E., Mining: The State of Missouri, by Walter Williams, 1904, p. 179.

${ }^{b}$ Eng. and Min. Jour., New York, vol, 76, 1903, p. 739. 
inaccessible. It is not surprising, therefore, that promising mineral prospects have been, in some instances, inadequately investigated.

Copper occurs as far south and west as in the Joplin zinc district, where chalcopyrite is very common and many of the copper oxides, carbonates, etc., have been recognized. It is to be noted, however, that the areas in which it occurs so abundantly as to have induced efforts to mine it are all located near the core of crystalline rocks, a

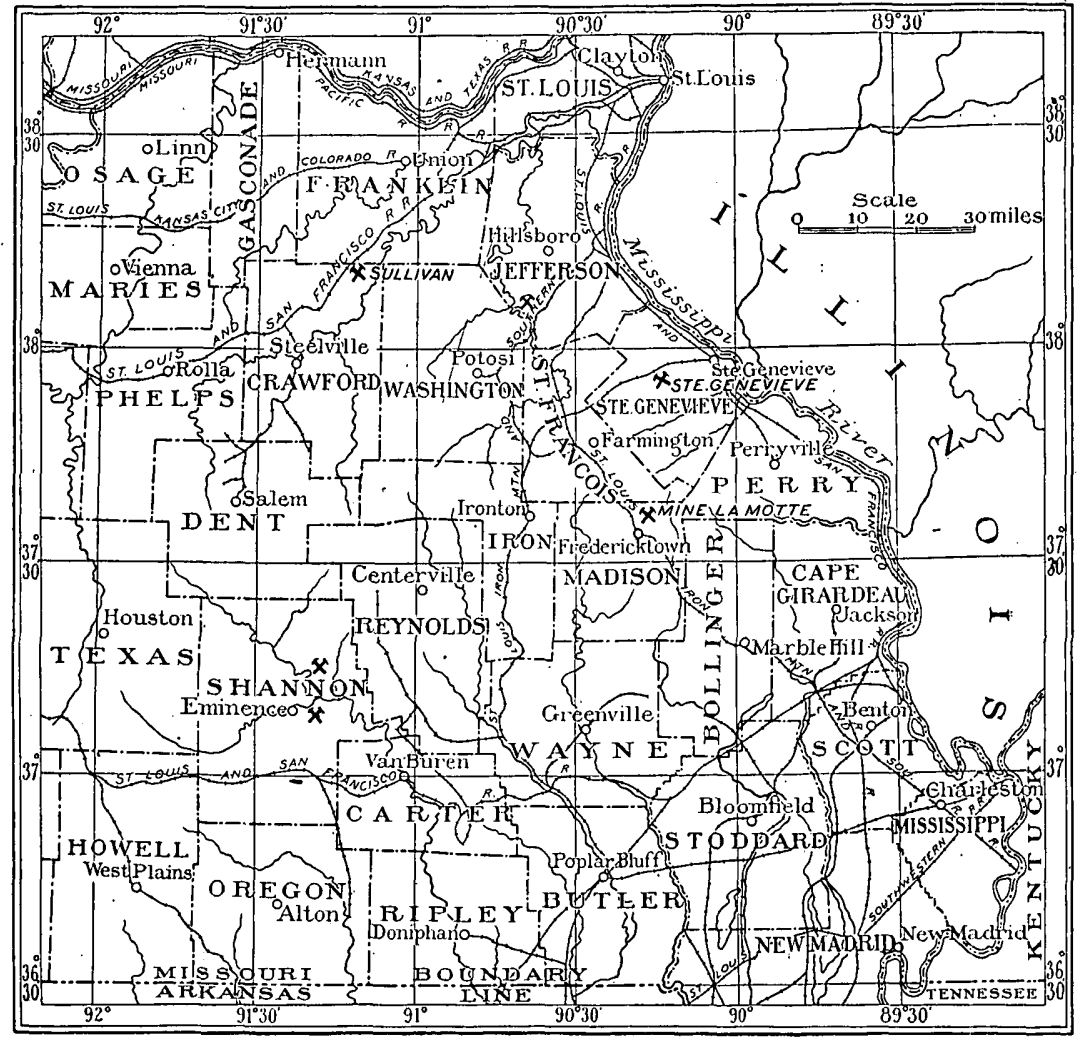

FIG. 1.-Sketch map showing location of copper deposits.

relation which becomes more striking as the individual occurrences are examined. The pre-Cambrian age of these rocks is well attested, and there is no evidence of any later igneous activity in the district. A possible exception is the occurrence of a dike of graphic granite in Camden County, which Professor Shepard has described. ${ }^{a}$ Here an intrusion took place in post-Ordovician and probably post-Devonian time. It does not seem, however, to have been accompanied by important mineralization, and has no apparent connection with any copper deposit.

${ }^{a}$ Shepard, E. M., Spring system of the Decaturville dome, Camden County, Mo.: WaterSup. and Irr. Paper No. 110, U. S. Geol. Survey, 1904, pp. 113-125. 
Classification and synonymy of the formations of the "Magnesian" or "Ozark series" in Missouri.

\begin{tabular}{|c|c|c|c|c|c|}
\hline System & \multicolumn{2}{|c|}{ Series. } & Formation. & Thickness. & Synonyms. \\
\hline \multirow{3}{*}{. } & \multirow{6}{*}{ 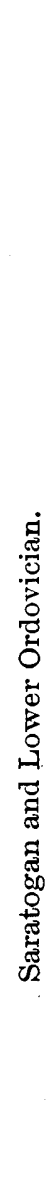 } & & Joachim limestone: & $0-150$ & $\left\{\begin{array}{l}\text { First Magnesian limestone. } \\
\text { Folley limestone. }\end{array}\right.$ \\
\hline & & & $\begin{array}{l}\text { St. Peter ("Crys- } \\
\text { tal City") sand- } \\
\text { stone. }\end{array}$ & $0-200$ & $\left\{\begin{array}{l}\text { First or Saccharoidal sand- } \\
\text { stone. } \\
\text { Cap-au-Grès sandstone. } \\
\text { Pacific sandstone: } \\
\text { "Key sandstone" in Yell- } \\
\text { ville district of Arkansas. }\end{array}\right.$ \\
\hline & & & $\begin{array}{l}\text { Jefferson City lime- } \\
\text { stone. }\end{array}$ & $50-250$ & $\left\{\begin{array}{l}\text { Second Magnesian lime- } \\
\text { stone. } \\
\text { Winfield limestone. } \\
\text { Finley limestone. }{ }^{b} \\
\text { ?Marshfield sandstone. }\end{array}\right.$ \\
\hline \multirow{5}{*}{ 莺 } & & 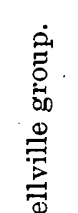 & $\begin{array}{l}\text { Roubidoux forma- } \\
\text { tion. }\end{array}$ & $70-225+$ & $\left\{\begin{array}{l}\text { Second sandstone. } \\
\text { Moreau sandstone. } \\
\text { St. Elizabeth formation } \\
\text { and Bolin Creek sand- } \\
\text { stone member. } \\
\text { ?Marshfield sandstone. } \\
\text { ?Bolivar sandstone. }\end{array}\right.$ \\
\hline & & $\begin{array}{l}\dot{1} \\
\dot{0} \\
\dot{0} \\
0 \\
0 \\
0 \\
0\end{array}$ & $\begin{array}{l}\text { Gasconade lime- } \\
\text { stone. }\end{array}$ & $450-650$ & $\left\{\begin{array}{l}\text { Third and Fonrth Magne- } \\
\text { sian limes ton es and } \\
\text { Third sandstones. } \\
\text { Includes Osage limestone. } \\
\text { Cole Camp sandstone of } \\
\text { Winslow; also Gascon- } \\
\text { ade limestone, Gunter } \\
\text { sandstone, and Proctor } \\
\text { limestone of Ball and } \\
\text { Smith. } \\
\text { Lesueur limestone. }\end{array}\right.$ \\
\hline & & 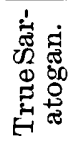 & Elvins formation & $0-120$ & $\left\{\begin{array}{l}\text { Basal part of the Potosi } \\
\text { limestone and the "Po- } \\
\text { tosi slates and conglom- } \\
\text { erates" of Nason. }\end{array}\right.$ \\
\hline & \multirow{2}{*}{\multicolumn{2}{|c|}{ 丞 }} & $\begin{array}{l}\text { Bonneterre lime- } \\
\text { stone. }\end{array}$ & & $\left\{\begin{array}{l}\text { ?Fourth Magnesian lime- } \\
\text { stone (in part). } \\
\text { Decaturville limestone. }\end{array}\right.$ \\
\hline & & & La Motte sandstone & $0-300$ & $\left\{\begin{array}{l}\text { Second sandstone of Shu- } \\
\text { mard (in part). }\end{array}\right.$ \\
\hline & \multicolumn{2}{|c|}{1} & \multicolumn{3}{|c|}{ Archean granites and porphyries. } \\
\hline
\end{tabular}

a The names "Folley limestone," "Cap-au-Grès sandstone," and "Winfield limestone," together with a number of other new names, were published by Keyes in a paper entitled Some geological formations of the Cap-au-Grès uplift: Proc. Iowa Acad. Sci., vol. 5, 1898, pp. 58-63.

bThe names "Finley limestone," "Marshfield sandstone," and "Decaturville limestone" appear in a provisional table of geologic formations in Missouri by Shepard, E. M., Bull. Brad. Geol. Field Sta., 1904, p. 42. 
GEOLOGY.

\section{FORMER CLASSIFICATIONS OF THE ROCKS.}

The geologic formations containing the copper deposits of Missouri, described in this paper, all belong to that difficult and muchdiscussed series of rocks commonly known as the "Magnesian series" and more recently called the "Ozark series." Many and diverse attempts at subdividing and classifying these rocks have been made in the last fifty years. None has proved wholly satisfactory, and some have merely increased the confusion.

It is obviously impracticable to discuss the numerous and important problems connected with the Ozark series of rocks except in the briefest manner at this time. Besides, as it is proposed to continue the investigation of the stratigraphic problems during the coming field season, it would be unwise to hamper the final conclusions by a preliminary publication of views necessarily based on incomplete field observations and office studies. Still, these investigations have been sufficiently extended to induce the belief that the results here presented will not be materially modified.

In order that the following résumé may be made as intelligible as possible, it has been thought well to precede it with a table giving (1) the successive thickness and provisional classification of the formations, (2) the names of the formations that after a careful study of the matter have seemed to accord best with the demands of the rules of nomenclature, especially the rule of priority, and (3) the principal synonyms of each name.

Swallow's scheme.-In 1855 Swallow and his assistants ${ }^{b}$ published a scheme of classification of the rocks in which the subdivisions were based primarily upon the separation of the rock by beds of sandstone usually much thinner than the limestone. These sandstones were regarded as widespread and constant in position, and hence of high value in the correlation of the beds of more or less magnesian limestones between them. Fossils being rare, and generally in an unfavorable state of preservation when found, and the older geologists seeming to have had confidence in the persistence of the sandstone beds, the numbering of the beds from above downward promised to be a happy solution of the difficulties.

From the beginning, however, of the later surveys of the State of Missouri, under Winslow, Keyes, and Buckley, the inadequacy and

\footnotetext{
"Broadhead, G. C., Am. Geol., vol. 8, 1891, p. 33. The term "Ozark series" is frequently employed in the following pages in a quoted sense. In the final nomenclature of the rocks of Missouri there can be no place for the term as defined by Broadbead. In the meantime, however, it is a convenient alternative for "Magnesian séries."

${ }^{b}$ Swallow, G. C., First and Second Ann. Repts. Missouri Geol. Survey, 1855, pp. 114-131.
} 
imperfections of Swallow's classification became more and more apparent. The impracticability of the prevailing mode of subdivision soon became obvious. They found not only more sandstones than were accounted for in Swallow's scheme, but also that most of these beds were mere lenses, appearing and disappearing with disconcerting frequency and irregularity.

Nason's work.-Nason, ${ }^{a}$ in 1892, was the first to indicate these facts. However, in the course of his work on the rocks of the Ozark series he found that the general horizon that had been more constantly identified correctly than any of the other beds by Swallow and his assistants, and called the "Second sari.stone," was really a persistent formation over a large part of the Ozark uplift. The name Roubidoux sandstone therefore was proposed by him as a geographic designation to take the place of Second sandstone. At the same time he proposed to call the formation beneath the Roubidoux the Gasconade limestone. Perhaps it is unfortunate that Nason failed to fix the lower limit of his Gasconade formation. From another view it is rather fortunate that he did not, since with the fuller knowledge of the entire section now available the want may be supplied in a manner more in accord with the best interests of stratigraphy than might have been possible in 1892 .

Nason's supposition respecting the probable equivalence of the Roubidoux sandstone and Swallow's First or Saccharoidal sandstone as exhibited at Pacific and Crystal City (op. cit., p. 115) is unquestionably an error, and doubtless was occasioned by his justifiable loss of confidence in the ability of the geologists of the first survey to discriminate between the several beds of sandstone and limestone by lithologic characters only. It arose further, and perhaps especially, from the fact that neither he nor any of the geologists before him recognized that the true First or Saccharoidal sandstone has been quite generally removed from the central areas of the Ozark Plateau. The sandstones identified by Shumard and other geologists in these central areas, and also along the western border of the outcrop of the Magnesian series, are not the same as the true "Saccharoidal sandstone" on the eastern flanks of Ozarkia, as this ancient land has recently been called, but are in nearly all cases, as believed or suspected by Nason, older and much thinner beds. Some of them may belong to the Roubidoux, most of them probably to the Jefferson City limestone, while a few-particularly those at the contact with the overlying Devonian or Carboniferous rocks-are the initial.deposits of much younger formations. As a rule, it may be stated that where no later Ordovician rocks intervene between the "Magnesian series" and the Devonian or lower Carboniferous beds that generally rest

a Nason, F. L., Report on iron ores: Missouri Geol. Survey, vol. 2, 1892, pp. 85-115. 
on the eroded surface of the older magnesian limestones on the western and southern flanks of the Gark uplift, the true "Saccharoidal sandstone" is missing entirely, it, together with more or less of the underlying limestone, having been removed by erosion prior to the Devonian and Carboniferous overlap. The long interval during which Ozarkia was elevated above sea level and subjected to erosion agencies was quite sufficient to remove the sandstone, since it comprised the later half of Ordovician, the whole of Silurian, and the greater part of Devônian time.

Winslow's table.-In 1894 Winslow published a table of formations in the lead districts of Missouri. ${ }^{a}$ A number of new names for aivisions of the rocks under consideration are contained in this table, and in the matter following the table brief descriptions of most of the formations are given. The whole series in the southwestern district is included under one name-White River limestone. This name had unfortunately been used and is in good standing for a Tertiary formation, and hence it is not available in this connection. Except for this fact it might very well have been employed instead of the name Yellville limestone recently proposed by Adams ${ }^{b}$ for rocks in northern Arkansas holding precisely the same position as the rocks of the Magnesian series along White River. Along this river, however, the top of the series is minus both the Joachim (First Magnesian) limestone and the St. Peter (First) sandstone, while the lowest rocks outcropping belong to the Gasconade formation.

In Winslow's table the Magnesian or Ozark series in central Missouri is as follows, beginning at the top: Roubidoux or Saccharoidal sandstone, Jefferson City limestone, Moreau sandstone, Osage limestone, Cole Camp sandstone, and Proctor limestone. These formations presumably are equivalent to Swallow's divisions of the series in the same area, the only difference being that geographic names are used instead of lithologic. However, for reasons already pointed out, it was a mistake to employ Nason's name, Roubidoux, for the First or Saccharoidal sandstone instead of for the Second sandstone, which alone has a right to that name, and Roubidoux doubtless will displace the name Moreau, proposed by Winslow. As for the other names, Jefferson City limestone is proposed for Swallow's Second Magnesian limestone, Osage limestone for his Third Magnesian limestone, Cole Camp sandstone for the Third sandstone, and Proctor limestone for the Fourth Magnesian limestone. The last three divisions, as will be explained on a later page, all fall within the Gasconade limestone of Nason, according to the present writers' interpretation and definition of this formation.

a Winslow, Arthur, Lead and zinc deposits: Missouri Geol. Survey, vol. (i, 1894, p. 331.

${ }^{b}$ Adams, George I., and others, Zinc and lead deposits of northern Arkansas: Prof. Paper U. S. Geol. Survey No. 24, 1904, pp. 18-20. 
In the third column of his table Winslow presents an altogether different subdivision and nomenclature, which is proposed for the series in southeastern Missouri: Beginning at the top, the formations are as follows: (1) Joachim limestone, this being the name proposed for the First Magnesian limestone of Swallow; (2) Crystal City sandstone, the geographic name proposed for the "Saccharoidal sandstone;" (3) Potosi limestone, which is assigned by Winslow to the interval corresponding to the Jefferson City limestone and Moreau sandstone in central Missouri; (4) St. Joseph limestone, which is placed opposite the Osage limestone, Cole Camp sandstone, and Proctor limestone, in the central Missouri column of the table; and (5) La Motte sandstone, which is placed at the base of the Ozark series.

Concerning the Joachim limestone and the Crystal City sandstone, the present writers believe these to be well-marked formations and properly correlated by their author. The Potosi limestone, however, corresponds to much more of the geologic column in central Missouri than is indicated by Winslow's table. As stated above, he made it correspond with only the Jefferson City limestone and the Roubidoux (Moreau)_sandstone; while we regard it as including also the Osage limestone, the Cole Camp sandstone, and the Proctor limestone of central Missouri.

The St. Joseph limestone includes two easily distinguishable lithologic units. According to the view of the Potosi formation just expressed, both the Bonneterre and Elvins formations--the two beds comprised in the St. Joseph limestone-are distinctly older than the Proctor limestone, or its equivalent, the "Fourth Magnesian limestone" of Swallow. The stratigraphic relations and fossil contents of the successive beds in the sections studied by the writers in southeastern and central Missouri, it is believed, establish the truth of these opinions. For a brief discussion of these features of the problem the reader is referred to the remarks following the succeeding descriptions of the formations in question. As to the La Motte sandstone, probably all agree that the name was. well chosen and that the formation itself is an excellently defined lithologic unit lower than all the limestones now comprised in the Ozark series.

Keyes's report.-In the year 1895, following Winslow's publication, Keyes published a report upon the section exposed in the La Motte quadrangle of Missouri. ${ }^{a}$ In this area only the lower part of the Ozark series occurs. This he divides into three formations, the La Motte sandstone at the base, the Fredericktown dolomite next above, and the Lesueur dolomite at the top. All the beds of the lastnamed formation occurring in the La Motte quadrangle belong in the

\footnotetext{
a Keyes, Charles R., Missouri Geol. Survey Sheet Rept. No. 4, Mine La Motte, 124 pages. (Later bound in vol. 9.)
} 
Gasconade limestone of Nason. The new name; therefore, was superfluous. It would seem to have been better to employ Winslow's rather broad term Potosi limestone. The name Fredericktown covers the same beds to which Winslow applied St. Joseph. The La Motte sandstone evidently is the same formation as that for which Winslow proposed the name.

Nason's later discoveries.-In 1901 Nason published a short paper on "The geological relations and age of the St. Joseph and Potosi limestones of St. Francois County, Missouri." a This paper contains at least three features of importance, viz: (1) The first description of a shale and conglomerate zone separating the St. Joseph and Potosi limestones, the discovery of which had been announced by the same writer earlier in the year ${ }^{b}(2)$ the announcement of the discovery by him of sufficient fossils from the conglomerate bed, which he attaches to the base of the Potosi limestone, to enable Dr. C. E. Beecher to determine the age of the bed as "Middle or Upper Cambrian;" and (3) the first publication in a scientific journal of recognized standing of the name "Bonneterre limestone."

Nason did not overestimate the stratigraphic importance of this conglomerate bed. Its base marks an important break, no less than that between the Upper and Middle Cambrian. A very similar contact, with almost exactly the same kind of conglomerate and fauna above it, commonly defines the limits of these two divisions of the Cambrian, not only in Missouri, but also in Indian Territory, central Texas, and at least locally in the upper Mississippi Valley. Classifying the "conglomeratic zone" with the Potosi is believed to have been a mistake, the writers preferring to make it the lower and greater part of a distinct formation, for which the name Elvins formation is proposed. Finally, the name Bonneterre limestone, used incorrectly and without comment as an alternative for Winslow's St. Joseph, is the most appropriate and probably the only strictly available designation for the limestone beneath the conglomerate of the Elvins formation.

Ball and Smith report.-An important contribution to the literature of the Ozark series appeared in 1903 in a volume by Ball and Smith on "The geology of Miller County." c In this report very full descriptions and numerous detailed sections are given of the formations corresponding, at least in a general way, to the Second, Third, and Fourth Magnesian limestones and the First, Second, and Third sandstones of Swallow's classification. The nomenclature

a Nason, F. L., Am. Jour. Sci., 4 th ser., vol. 12, 1901, p. 358.

' Nason, F. L., Am. Jour. Sci., 4th ser., vol. 11, 1901, p. 396.

- Ball, Sidney H., and Smith, A. F., Missouri Bureau of Geology and Mines, 2d ser., vol. 1, ¡903, 197: pages.

Bull. 267-05 M-2 
of the formations presented in this valuable work differs in several respects from that in the table on page 12 of this paper. For instance, the name Gasconade limestone is applied by the authors mentioned to Swallow's Third Magnesian limestone. According to our view, Nason, who is responsible for the name, included not only the Third, but the Fourth Magnesian as well, in his sections of the formation. The Gasconade limestone, therefore, if this name be used at all, should extend downward so as to include the Gunter sandstone and the Proctor limestone. This is not to say, however, that the Gasconade limestone in Miller County is not divisible into three members (or formations, perhaps), worthy of being mapped as separate lithologic units. Indeed, such a division seems not only practicable, but even very desirable through a large part of the northwestern half of the Ozark uplift. In the southeastern half, however, the two limestone members and the intermediate Gunter sandstone, though in a general way recognizable, do not seem to be as readily separated. Indeed, the -Gunter sandstone, which is so definite a bed in Miller and adjoining counties, has entirely lost its identity or can not be distinguishèd from a number of similar sandstones occurring at about the same horizon. In Yell County, Ark., there seems to be no sandstone a't all in the corresponding portion of the Gasconade. In Ste. Genevieve County, Mo., on the other hand, the upper half of the formation contains a number of sandstones, but it is impossible to say that any one is equivalent to the Gunter.

The St. Elizabeth formation of the Miller County report seems to be essentially, if, indeed, not exactly, the same formation earlier named Roubidoux sandstone of Nason.

As regards the "Pacific sandstone" of the Miller County report, which Ball and Smith correlate with the First or Saccharoidal sandstone of Swallow, it seems to the present writers highly improbable that it is the same as that outcropping at Pacific, Crystal City, and many localities on the eastern flank of the Ozark uplift. Some of the supposed occurrences of this bed may be thin lenses of sandstone in the Jefferson City limestone, but the majority probably are later than Ordovician-possibly Devonian or Carboniferous. At the top of one section (op. cit., p. 80) pieces of "dolomite resembling cotton riock" occurred above the sandstone. These, it is said, "may be remnants of the First Magnesian limestone," but, for many reasons which can not be given at this time, the whole exposure described on the page mentioned is believed to belong to the Jefferson City limestone. Finally, the name "Pacific sandstone" seems entirely unnecessary. If a Missouri name for the true Saccharoidal sandstone is preferred to the adoption of St. Peter sandstone, with which the First sandstone doubtless is identical, then it should be Crystal City sandstone, ? name proposed by Winslow several years before. 
GENERAL REMARKS ON THE “OZARK SERIES” OF ROCKS.

As has been already stated, none of the classifications and subdivisions of the Ozark series of rocks, briefly discussed in the foregoing pages, has proved wholly satisfactory. An arrangement that would be above criticism is perhaps impossible. Some of the beds vary so greatly from placeto place that it is difficult to follow them over any considerable area. The difficulties are greatly enhanced by the appar(nt scarcity and imperfect preservation of the fossils and by the general similarity in lithologic character exhibited by widely separated beds in the series. The occurrence of beds of sandstone at intervals in the mass of magnesian limestones was early seized upon as affording a ready means for dividing the series into formations; but experience gradually taught that most of the sandstones were mere lenses, irregularly developed at unequal intervals and occurring locally as many successive beds or with only two or three. In the northern and central parts of the Ozark Plateau the sandstone beds seem to be more regularly developed than elsewhere, and here they are of considcrable use in working out the stratigraphy. Along the southern border, however, only the First or St. Peter sandstone seems to have been so well developed as to mark a definite horizon. Along the eastern border, especially in Ste. Genevieve County, the upper half of the series is thicker than usual. It here contains so many beds of sandstone that it is very difficult to establish the boundary line between the Gasconade and Roubidoux formations and between the latter and the overlying Jefferson City limestone.

A careful study of the cherts has yielded perhaps the most reliable of the lithologic criteria employed in discriminating the three formations of the Potosi group. As this group covers by far the greatest part of the Ozark area, the opportunities for-studying and testing the value of certain varieties of chert as indices of particular horizons are unusual. Having checked the results in many instances by evidence afforded by fossils, which really are much commoner in these rocks than is generally believed, we have gradually become convinced that the story as told by the cherts is rarely at fault. The merc presence of considerable quantities of chert is at once reliably indicative of the Potosi group, the underlying limestones being practically free from it, as is true also of the Joachim limestone at the top of the series. It is to be remembered, however, that the proportion of chert in a given bed may vary greatly in near-by exposures. This is shown often very strikingly in opposite faces of a hill, the one side of which forms a bluff, the other a gentle, soil-covered slope. In cases of bluff exposure-where side erosion is active and takes place under conditions very different from those prevailing on gentle slopes-the limestone beds may often seem to be almost entirely with- 
out chert, but on the other side of the hill the surface may be thickly strewn with it.

The classification presented in tabular form on page 12 is based upon more or less extended investigations in all parts of the field. The formations are discriminated chiefly by lithologic differences, and limited in most cases by at least local stratigraphic discordances. As the formations are intended to express as much as possible lithologic units deemed worthy of being mapped separately, the evidence of the fossils found in them was accorded secondary rank. How. ever, in the determination of the age of the deposits the faunas were depended upon almost exclusively.

It will be observed that the division between the Ordovician and Cambrian is drawn as a dotted line opposite the Roubidoux member of the Potosi. This seeming indecision concerning the point at which the line should be drawn is not due to the absence of a fauna, for we have succeded in collecting a large one, but because of the conflicting elements contained in it. The trilobites from the Gasconade and the lower part of the Roubidoux are, so far as observed, nearly all of types that hitherto have been regarded as strictly indicative of the Upper Cambrian. On the other hand, the numerous gasteropods and fewer brachiopods found in the same beds are nearly all of Lower Ordovician types.

\section{DESCRIPTION OF FORMATIONS.}

LA MOTIT SANDSTONE.

This formation generally consists of thick, massive beds of sandstone. Toward the top it is often thinly bedded or flaggy. The color of the sandstone is usually'yellow or reddish brown, with occasional layers almost white. It is generally composed of large grains of quartz in a matrix of smaller grains. In the upper half of the formation the matrix is often calcareous, the proportion of limy material usually increasing upward until the rock grades into a sandy limestone. Near the top beds of limestone may alternate with layers of sandstone, and in such cases the transition to the overlying Bonneterre limestone may be gradual. Near the base there are frequently layers containing coarse grit and quartz pebbles and others with small pebbles of granite and porphyry. The upper beds are often chloritic, but so far as observed no part of the formation is ever micaceous.

The maximum thickness of the La Motte sandstone is not less than 250 feet, and in the bottoms of the basins adjacent to granitic areas, which doubtless were the main sources of supply, the thickness probably exceeds 300 or possibly 400 feet. From this it dwindles down to 
nothing along some of the old shore lines, where it is overlapped by the limestones of the next formation.

The principal areas of outcrop occur around the granite hills in the western half of Ste. Genevieve County and on the eastern flanks of the old Archean hills in Madison and St. Francois counties. How far from these areas this formation extends beneath the covering of higher rocks can not now be said. Possibly it is widely distributed, and it may even be continuous with what is believed to be nearly contemporaneous Middle Cambrian sandstones in Indian Territory and in the upper Mississippi Valley. However, considering the granitic rocks in southeastern Missouri as the principal if not the only source from which its quartz grains might be derived, it does not seem likely that the formation - at any rate, as a sandstone-could have attained any considerable thickness far from its present main outcrops. Masses of quartzite, etc., occurring apparently at the base of the Bonneterre limestone in the southern part of Camden County, where profound disturbances have brought this limestone to the surface, may be silicified blocks of a thin extension of the La Motte sandstone.

In the area of the St. Francis Mountains a conglomerate, consisting mainly. of pebbles of porphyry in a slaty or sandy matrix, often underlies the La Motte sandstone. In the Missouri Survey reports this bed is referred to under two names-Pilot Knob conglomerate (Keyes) and Iron Mountain conglomerate (Winslow). The age of the bed is variously interpreted, some considering it, especially at Pilot Knob, as Algonkian; in other cases it seems not to be older than the lower part at least of the La Motte sandstone. The truth of the matter probably is that the conglomerate is primarily the initial deposit of the invading early Cambrian, and that during the subsequent deposition of the La Motte sandstone the conglomerate continued locally to be formed near the shore, perhaps more particularly where this was steep. The bed, therefore, it not to be regarded as a formation wholly beneath and older than the La Motte sandstone.

\section{BON NETERRE LIMESTONE.}

As a rule this formation consists of more or less heavily bedded, granular, and highly magnesian limestones. In texture these generally are compactly crystalline and often minutely vesicular, with dolomite crystals lining the cavities. A few beds are fine grained. The usual color is light or dark gray, especially when fresh, a yellowish tint being commonly acquired on weathering. Locally the mass may contain beds of a pink or of a more decidedly red color. Chert and drusy quartz seem to be entirely absent. Some of the beds, especially in the lower part of the formation, contain much chlorite, in places sufficient to give them a decidedly green color. 
Toward the base of the formation it contains some silica. This occurs as grains of sand in the limestone. The contact with the underlying La Motte sandstone is rarely sharp, the two formations often appearing to grade into each other. The basal portion commonly also includes one or more thin beds of bluish shale. Where the top of the formation has suffered least from the widespread erosion that took place prior to the deposition of the Elvins formation it grades upward from the massive limestones into a thinly bedded zone, and this finally into a bed of blue shale. Locally the thinly bedded and shaly zones appear to be absent entirely.

Fossils are rare in this formation, except in the shaly bed near the base. This is crowded with a species of Lingulepis, related to L. lambornei Meek. Fragments of other fossils occur with this shell. A few specimens of trilobites and of orthoid shells related to Billingsella were observed also in the shales at the top of the formation. These fossiliferous horizons, however, have not been thoroughly exploited. The species so far found are comparable to those characteristic of the Middle Cambrian.

Like the La Motte sandstone, this formation varies greatly in thickness, and seems even to wedge out on the old hillsides. In the vicinity of Mine La Motte and Fredericktown, where the basin is comparatively shallow, the maximum thickness probably does not exceed 200 feet, or possibly 250 feet. Farther north, in St. Francois County, deep drillings show it to be much thicker, the greatest thickness probably being nearly 500 feet. Winslow gives the maximum thickness in the vicinity of Flat River as "somewhere near 600 feet," but this estimate doubtless includes the whole, or at least a large part, , of the overlying Elvins formation.

The Bonneterre limestone is the prevailing surface rock in the southeastern lead-mining district of Missouri. The formation probably underlies a large part of the Ozark uplift, but it does not again come to the surface within the borders of the State except in a small area near the southern boundary of Camden County. Here it occurs as a noncherty, massive, crystalline dolomite, standing nearly on edge about a dike of graphic granite. On account of the excessively disturbed character of the outcrop and the brevity of the time devoted to its study, the thickness of the formation was not determined exactly. It is safe to say, however, that it is not less than 200 feet.

That the base of the formation is exposed at this locality is indicated by the presence of a bed of limestone filled with rounded grains of quartz and of quartzite bowlders believed to be silicified masses of La Motte sandstone. Closely associated with these, and apparently overlying the calcareous sandstone, is a bed of fine conglomerate that is believed to be the basal layer of the Bonneterre limestone. 
The pebbles in this conglomerate consist principally of greenish-blue shale and fragments of limy sandstone abundantly specked with a green mineral supposed to be chlorite.

In southeastern Missouri, except in the few places where the formation overlaps the underlying sandstone and rests on the Archean, the base seems to be entirely conformable with the top of the La Motte sandstone. The upper boundary, however, as intimated above, is variable. Sometimes there is a considerable body of thin limestones interbedded with shale at the top that at other points is much thinner or perhaps may be wanting entirely. This irregularity of the top is due to an erosion interval, in which much of the shaly top of the formation was removed. There is, consequently, an unconformable contact between the Bonneterre and Elvins formations. In the outcrops, which occur chiefly in the marginal portions of the old basins, this unconformable contact is marked by one or more thin beds of lenticular pebbles. Where observed it generally occurs within what might otherwise appear as a continuous deposit of rapidly alternating thin limestones and shales. On this account it may be difficult, and in some cases impossible, to distinguish the upper part of the Bonneterre formation from the Elvins formation in records and cores of drill holes. In the outcrops, however, the boundary between the two may be drawn with little trouble. Considering that this line probably separates the Middle Cambrian from the Upper Cambrian, and that it may eventually mark the boundary between two systems, its stratigraphic importance becomes clear.

ELVINS FORMATION.

This name is proposed for the shales, shaly limestones, and more or less earthy dolomites that in St. Francois County intervene between the shaly top of the underlying Bonneterre limestone and the cherty limestones of the Potosi group above. In the vicinity of Elvins and Flat Rock the base of the formation is marked by a zone 6 to 10 feet thick, consisting mainly of indurated platy shale. At the bottom of this zone is a layer, generally only a few inches in thickness, that is largely made up of lenticular pebbles usually arranged edgewise in a subcrystalline limy matrix. At the top of the zone there is usually a similar "edgewise layer," while between the two layers one or more smaller lenses of conglonerate may be observed. In the Elvins section given on pages $24-25$ a bed of nearly white, compact, and apparently not highly magnesian limestone occurs about 8 feet above the base of the formation, which is well exposed in the railroad cut a half mile north of the Illinois Southern Railroad depot at Elvins. In the unfinished deep cut nearer the depot 
this layer is broken up into a series of large, bowlder-like masses that may be of concretionary origin.

The following detailed section of the typical exposures of the formation will give a better idea of the lithologic and other characters than could be acquired from a general description:

Section of the Elvins formation along the Illinois Southern Railroad between Elvins and 1 mile north.

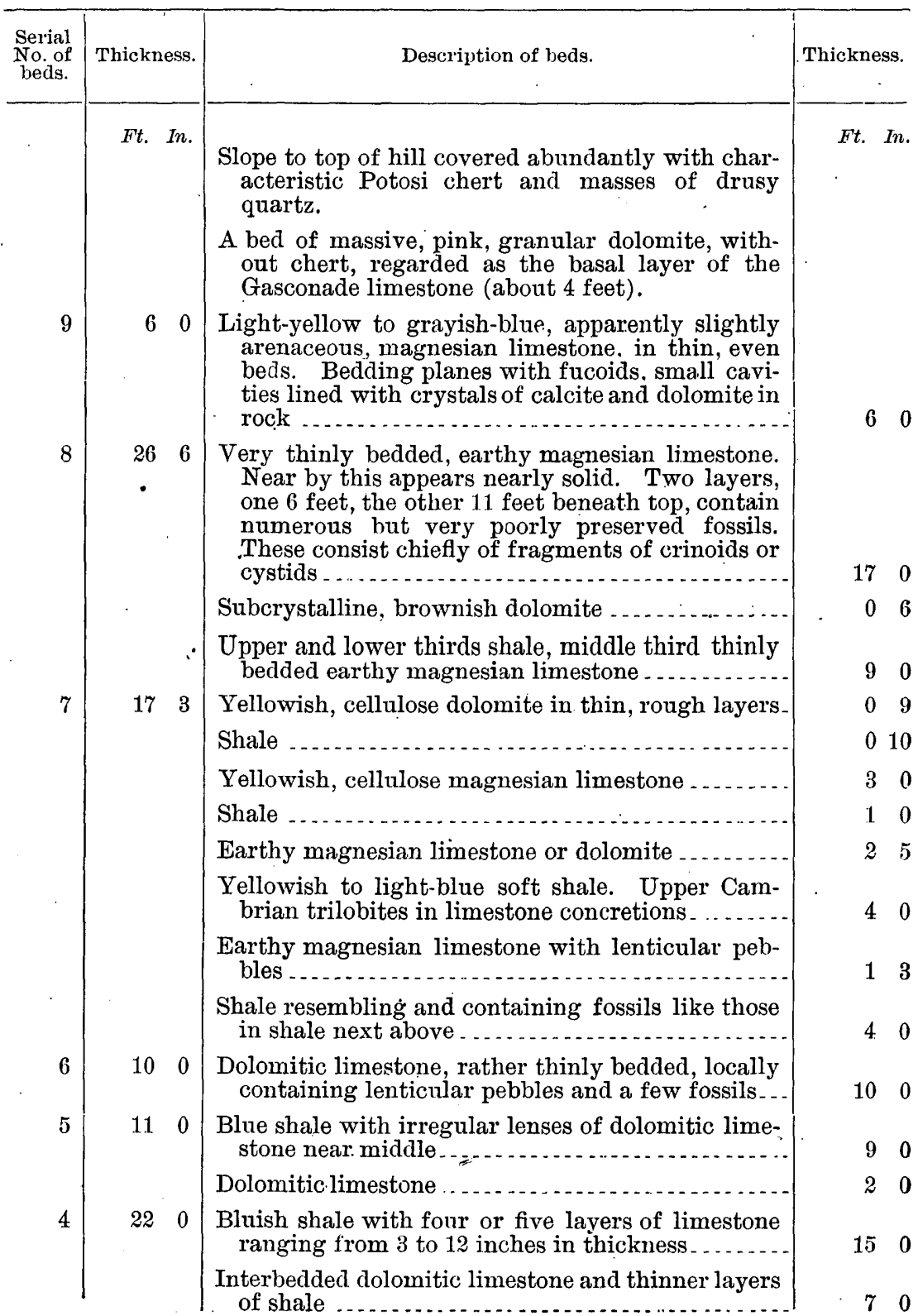


Section of the Elvins formation along the Illinois Southern Railroad between Elvins and 1 mile north-Continued.

\begin{tabular}{|c|c|c|c|}
\hline $\begin{array}{l}\text { Serial } \\
\text { No. of } \\
\text { beds. }\end{array}$ & Thickness. & Description of beds. & Thickness. \\
\hline \multirow[t]{2}{*}{3} & Ft. In. & Blue shale, increasing in hardness downward & Ft. ${ }_{6} \mathrm{In}_{0}$ \\
\hline & & 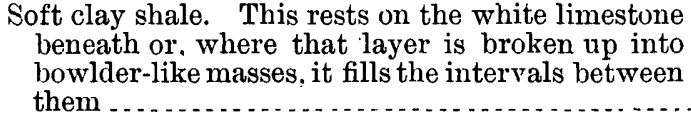 & \\
\hline 2 & $0-3 \quad 0$ & $\begin{array}{l}\text { White, compact, apparently not highly magnesian } \\
\text { limestone, occurring either as a continuous layer } \\
\text { or as bowlder-like remnants embedded in shale. } \\
\text { The "remnants"' are usually flat on the lower } \\
\text { side and rounded above........................... }\end{array}$ & $0-3$ \\
\hline \multirow[t]{2}{*}{1} & 80 & $\begin{array}{l}\text { Indurated, platy shale, with a layer of "edgewise } \\
\text { conglomerate" at the base and often another at } \\
\text { top. (Base of the formation) }\end{array}$ & 8 \\
\hline & & Total thickness of Elvins formation.. & 113 \\
\hline
\end{tabular}

Beneath these beds the upper part of the Bonneterre limestone shows as follows:

Section of Bonneterre limestone exposed along railroad between Elvins and 1 mile north.

\begin{tabular}{r|c|c}
\hline $\begin{array}{c}\text { Serial } \\
\text { No. }\end{array}$ & Description of beds. & Thickness \\
in feet.
\end{tabular}

The lower part of this formation was well described by Nason in 1901. ${ }^{a}$ This writer also was the first to observe and note the importance of the beds of conglomerate marking the base and occurring also higher in the lower formation. Ranking the new horizon as a lower division of the Potosi limestone is believed to be an error, because (1) it constitutes a sharply defined lithologic unit; (2) its fauna is very different from that of the Potosi group, in wanting all the molluscan types which distinguish the Potosi from 
all preceding rocks; and (3) it seems that the contact with the overlying Potosi is, at least locally, unconformable.

The bed of pink dolomite assigned to the base of the Potosi in the foregoing section contains no chert nor drusy quartz, and in that respect differs decidedly from the overlying beds of the formation. It may therefore be regarded as more properly referable to the Elvins formation. This is not here, for the reason that it or a similar bed inaugurates the Potosi sedimentation in areas where the Elvinis formation is wanting. The similarity in lithologic character of the bed to the underlying rather than the overlying limestone is believed to result from a reworking of nonsiliceous matter derived from the dissolution of the underlying limestones. Beds above and beneath nearly conformable contacts are often very similar lithologically. The contact between the Bonneterre and Elvins formations affords a striking illustration of this.

Outcrops of the Elvins formation occur principally within St. Francois County. Here they are found in the slopes of perhaps all the hills that are capped by the residual cherts of the Potosi. The formation is frequently noticed also in drill holes in this county. In the northern part of the county these holes frequently pass through from 160 to as much as 250 feet of shales and chertless limestone, thus indicating a greater thickness for the formation than is found in the section measured at Elvins. However, it is at present not possible to say how much of these shaly beds underlie the conglomeratic layers and thus belong to the Bonneterre formation. On Rock Creek, east of Mine La Motte, no sign of the Elvins formation was observed, and the Potosi rested directly on the Bonneterre limestone.

\section{POTOSI GROUP. ${ }^{a}$}

The group of rocks included between the Elvins formation beneath and the St. Peter ("Crystal City") sandstone above is characterized by large quantities of various kinds of chert and drusy quartz. The group includes mainly limestones, nearly all more or less highly magnesian, the proportion of magnesia in some cases approximating that contained in a theoretical dolomite. Intercalated with the limestones, especially in the upper half or two-thirds of the series, are more or less irregularly developed and usually thin lenseor beds of sandstone.

\footnotetext{
a Winslow is responsible for the name Potosi as applied to a geologic formation. Unfortunately, in the original publication (Missouri Geol. Survey, vol. 6, 1894) the formaltion is not clearly defined, and as a rule its beds are referred to under the broader term St. Francois limestone. There is, therefore, some chance of conflict with the term Iesueur limestone proposed by Keyes the year following for essentially the same rocks. Most geologists and mining experts who have studied the Ozark rocks in southeastern Missouri have consistently used the name Potosi in the sense here adopted. 'This accords with Winslow's original intention as well as with his later definition of the term.
} 
As the group forms the surface rock over quite nine-tenths of the large area of Ozark rocks in Missouri and northern Arkansas, it is highly desirable to subdivide.it into such formations and members as may be required to illustrate the stratigraphy and structure of the region. Where the sandstone beds are fairly persistent, as in nearly the whole of the northwestern half of the area, they afford convenient datum lines upon which to base the desired subdivision. Careful use of certain types and beds of chert likewise aids in accomplishing the purpose.

Building upon the combined results of the efforts of Nason, Winslow, and Ball and Smith, we have recognized three major divisions that we believe may be carried with more or less accuracy over much the greater part of the territory in which the group is at the surface. These are, (1) the Gasconade limestone, at the base; (2) the Roubidoux formation, in the middle; and (3) the Jefferson City limestone. at the top. In the central and northern parts of the area the Gasconade limestone is further divisible into an upper and a lower limestone formation or member by an intervening thin but widely distributed and easily identified sandstone member, called the "Cole Camp sandstone" by Winslow and the "Gunter sandstone" by Ball and Smith. Locally other subdivisions are possible, and in the final mapping will doubtless be made.

During practically the whole of Potosi time the waters of the sea in the region now exposing the rocks of this age were shallow and fluctuating in depth. Frequently the bottom was raised above sea level, or it may be that the waters subsided and thus caused the bottom to be exposed. These emergences were more or less local and, according to the evidence available, must have varied greatly in the length of time through which each endured. Evidences of this condition are abundant. Intraformational conglomerates, suncracked beds, oolites, unconformities, due to exposure and erosion, and cases of abrupt change in deposition from limestone to sand. stone all occur frequently. The conglomerates in many cases indicate a considerable lapse of time. This is more particularly indicated for those containing pebbles of chert. Chert was only rarely present in this group of rocks when they were originally deposited. As it now occurs it is largely the result of segregation of siliceous matter under conditions of slow subaerial decomposition of the limestone. Hence the presence of rounded chert pebbles is strongly indicative of subaerial erosion and, for obvious reasons, of a longer time interval than is usually ascribed to an intraformational conglomerate. In these features the deposition of this part of the Ozark series differs from that of the corresponding parts in the Arbuckle limestone of Indian Territory and the Knox dolomite of the Appalachian Valley. The latter rocks were laid down in comparatively 
deep basins, while those of the Potosi group were spread unevenly over the summit of a low, broad dome. This explains also the occurrence in Missouri of a considerable fauna, whereas the corresponding deposits made in deeper waters are almost or entirely devoid of fossils. The Cambrii $n$ and early Ordovician faunas flourished only in shallow waters and vlong shore lines.

The shallows of the Ozark area afforded the necessary conditions for life, and here the main types of the Upper Cambrian faunaespecially the trilobites-continued in existence longer, while the Lower Ordovician fauna began earlier than is indicated elsewhere by faunas hitherto discovered.

As the copper deposits which constitute the principal subject of this contribution are contained, with one exception, in the rocks of this group, the major subdivisions will be described in some detail.

GASCONADE LIMESTONE.

In the report on Miller County, discussed earlier in this paper, the name Gasconade is restricted to the Third Magnesian limestone of Swallow. This makes it the same as the Osage limestone, proposed in 1894 by Winslow as a subdivision of the Gasconade limestone. The term Osage, however, had been used by Williams and Branner some years before for a group of Mississippian rocks, and, for this reason no doubt, Winslow's use of the name was objectionable to the authors of the Miller County report. Nason is responsible for the term Gasconade limestone. As adopted by Winslow, it became too broad, being placed opposite all the limestones beneath the Crystal City sandstone. This expansion of the meaning of the term was caused by the erroneous assumption that the Roubidoux and St. Peter sandstones were equivalent deposits. As employed here the Gasconade limestone embraces the chert-bearing limestones and included sandstones underlying the true Roubidoux, as determined by studies of some of Nason's typical localities, and overlying the strictly noncherty limestones of the Elvins and Bonneterre formations. This conception of the Gasconade, it is believed, is in accord with Nason's intention. As his deepest sections, along the Current River, in Shannon County, undoubtedly contain at least the upper part of the Proctor limestone, which is the basal member of the formation, we have, as is usual in such cases, drawn the lower limits of the formation at the first well-marked stratigraphic and lithologic change beneath the rocks included in the formations by Nason.

The Gasconade limestone consists chiefly of dolomitic limestone, varying greatly in color and composition and somewhat less in texture. The color of the majority of the beds is gray, in lighter and darker shades. Sometimes a bluish tinge is observable, but lightpink tints are more common. Other beds may be brown, green, or 
nearly white. As a rule, it may be said that bluish tints are more common in the lower parts than in the upper. The prevailing texture of the linestone rock is medium to coarse grained, crystalline, or granular, but comparatively fine-grained layers occur, and perhaps as commonly in one part of the formation as in another.

Several beds of sandstone occur, most of them small sporadic lenses in the upper half of the formation. One bed, the Cole Camp sandstone of Winslow and the Gunter sandstone of Ball and Smith, is more than usually persistent in the central and western parts of the area. In these, districts its thickness ranges from 2 or. 3 feet to 25 feet, and, as it is nearly always exposed, it constitutes an efficient boundary line between the Proctor limestone and the upper (Osage) limestone of the formation. The other divisions are more likely to confuse than help the geologist in working out the stratigraphy. In the southern part of the Orark area the Gunter sandstone, in common with the other sandstones interbedded with the limestones of the Potosi group, is either absent entirely or so irregularly developed that it hasilost its stratigraphic value. On the east side of the St. Francis Mountains, in Ste. Genevieve County, this sandstone bed is probably represented, but there are so many sandstones in the Potosi of this region that it can not be certainly distinguished.

Under usual conditions of subaerial decomposition the silica of the rocks is segregated in the form of amorphous and lamellar or vesicular chert, or as drusy quartz, in nearly all parts of this formation. However, under the present physiographic conditions, chert is on the whole more abundant in the upper part of the formation than in the lower, but this difference seems not to be due to any marked variation in the composition of the limestones composing the two parts, but; results rather from differences in the circumstances attending the decomposition and erosion of the upper member and those prevailing in the case of the lower. As is briefly suggested on page 27, rapid erosion is not conducive to the abundant segregation of chert. Therefore the lower, or Proctor, limestone, being rarely seen in the central area except in bluffs, appears to be characterized here by having much less chert than the upper division, which more commonly occupies upland ridges. In areas where the valleys are occupied by the Bonneterre limestone and the hills by rocks equivalent in age to the Proctor limestone, as in St. Francois and Madison counties, chert is extremely abundant in the lower as in the higher parts of the formation. It appears, therefore, that local superficial conditions are responsible for much of the unequal distribution of the chert.

Lamellar chert with drusy cavities occurs very abundantly in the lower and middle parts of the formation, but is comparatively rare in the upper beds. A highly characteristic form of chert, consisting of irregular rough stems, one-half inch or so in diameter, bound 
together by anastomosis into masses a foot or more in length, was observed at many localities. It occurs commonly enough beneath the horizon of the Gunter sandstone, but is especially abundant in the first 50 feet above that bed.

The cherts of the upper division embrace two common varieties that are believed to characterize this horizon over a large part of the Ozark area. They are both laminar varieties, and possibly of organic origin. One is a "Cryptozoon," differing from the C. minnesotensis, which is characteristic of the Jefferson City limestone in its looser and more irregular structure. The other is a very coarsely vesicular form, occurring in masses 2 or 3 feet thick and making up whole layers of that thickness. When followed into the bank these layers gradually pass into solid limestone, but even in these a similar horizontal lamination of the mass is observable. The laminæ are divided at intervals of about 2 inches into convex, minutely cellular plates, arranged one above the other so as to leave open spaces about equal to the thickness of the plates between them. This type occurs principally toward the top of the formation and is a reliable guide to one of the most prolific fossil horizons of the whole series. Thin conglomeratic layers, containing small chert pebbles and fragments of silicified and often sandy oolite, both commonly fossiliferous, occur with and above this coarsely vesicular type of chert.

Fossils occur more or less sparingly through all parts of the formation, but are generally distributed and of larger size in the upper: beds. They consist chiefly of low-spired and ventricose species of Gasteropoda. Associated with these are many fragments of trilobites, having unmistakable affinities with well-known Upper Cambrian species. Toward the base of the formation the fossils are sometimes abundant, but the species seen are not numerous, and, being' small, are easily overlooked.

In thickness this formation varies considerably from place to place. The greater amount of this variability seems to occur in the upper member, which was laid down under less uniform conditions than the lower. Locally, in St. Francois and Madison counties, the lower member also is thinner than usual, the variation in this case appearing to be due to overlap and consequent absence of the basal beds: The average thickness, doubtless, is at least 500 feet for the whole formation, while the maximum thickness probably exceeds 650 feet.

Concerning the relations of the Gasconade limestone to adjacent formations, it may be said that the basal contact is believed to be rather generally unconformable. It is certainly so locally, as is shown by the occurrence of certain fossiliferous bands, local evidence of overlap, and a comparison of the basal beds in different sections. However, on account of the abundant wash from overlying beds, exposures showing the contact in a satisfactory manner are very rare. In Cam- 
den County, where the base is shown in the vicinity of the pegmatite dike, a massive white sandstone, 20 to 30 feet thick, intervenes between the Bonnetẹre limestone and the cherty limestone of the Gasconade. This sandstone is probably to be regarded as the initial deposit of the Gasconade or possibly as in part representing the Elvins formation.

The top of the formation is less sharply defined; indeed, it is often. difficult to draw the line between it and the Roubidoux. There is no important unconformity between the two, the shallowing of the seas, which continued throughout and attained its culmination in the Roubidoux, having also prevailed in a less but increasing degree during Gasconade time.

\section{ROUBIDOUX FORMATJON.}

This interesting formation is extremely variable in its lithologic characters. It is, as described by Ball and Smith, ${ }^{a}$ who called it the St. Elizabeth formation, " a complex consisting of beds of sandstone, chert, quartzite, dolomite, and shale, all of very uncertain thickness and areal extent." Locally, as south of the Osage River in Miller: and adjoining counties, one of the sandstones is sufficiently persistent, and well developed to warrant napping it as a distinct member. In Miller County this member has been distinguished under the name Bolin Creek sandstone.

The dolomites of this formation are prevailingly thin bedded, fine grained, dense, and hard. In texture and conchoidal fracture they simulate chert. Beds of " cotton rock," an argillaceous, compact, finegrained and comparatively soft dolomite, are not uncommon. This variety of rock is nearly always thinly bedded, of a light-yellowish or: buff color, and generally exhibits dendritic markings on the bedding planes. Thin layers of shale are often associated or interbedded with it. Although beds of coarse- or medium-grained dolomite are occasionally found in this formation, it will be noted that, on the whole, the dolomites are conspicuously different from those constituting the bulk of the Gasconade formation.

Chert is found in greater abundance in the calcareous portions of this formation than in any other of this great series of dolomitic limestones. It occurs in various forms, the brecciated, conglomeratic, and cellulose or "honeycombed" varieties being the most common. Certain varieties found in the underlying and overlying formations, particularly those containing drusy cavities, are notably absent.

Perhaps the most marked and widely distributed type occurs at or near the base of the formation. Pecause of its position it aids materially in locating the boundary between the Roubidoux and the Gasconade. This chert is of dense structure and brittle and ranges

${ }^{a}$ Geology of Miller County : Missouri Bureau of Geology and Mines, 2d ser., vol. 1, 190:3, p. 50 . 
in color from nearly white to dark gray or even black. It is always brecciated and splintered, and the angular fragments, having been subsequently recemented by quartz or limonite, now form large rugged masses and often thick beds. This bed has been observed in Miller, Camden, Shannon, Franklin, and Ste. Genevieve counties.

Another variety that is locally of service in recognizing the upper part of the formation is distinguished by its cellular character. Similarly honeycombed chert, however, has been observed in the Gasconade formation in Shannon County, so that it is not strictly characteristic of the Roubidoux. The conglomeratic variety, which is largely made up of small, rounded, and often lenticular pebbles of chert, and commonly with admixtures of quartz and oolite grains, likewise occurs in the upper part of the underlying formation. This was found to be the case more especially in Shannon County.

The beds of sandstone found in this formation are its most variable part. Sometimes, particularly in the region west of Ste. Genevieve, where there are many such, the individual beds range in thickness from a few inches to over 30 feet. They vary greatly also in size of grain, color, and other features, but in these respects afford no means for distinguishing them from the occasional beds occurring in the Gasconade formation. Nevertheless, they very commonly exhibit certain features, such as thin and distinct bedding, ripple-marked and sun-cracked surfaces, and occasionally fucoidal markings, that together reliably indicate this horizon. Another peculiarity that was noted in many places is the presence, often in great number, of lightcolored, flattened, apparently argillaceous pebbles, or of lenticular spaces resulting from their disintegration and removal.

Fossil remains are not uncommon in most of the cherts and in some of the sandstones of this formation. They are, however, but rarely in a good state of preservation, the most of them having been macerated before being covered by deposits, while all have suffered from subsequent changes in the rocks. The species consist mainly of gasteropods. In most cases they are closely related to, if not the same as, those found in a more favorable condition in the upper part of the underlying formation. A neat undescribed form of Helicotoma, characterized by revolving rows of small nodes on the upper and lower sides of the volutions, appears for the first time in this formation and may be confined to it.

There is in some places evidence of unconformity, and hence of an erosion interval, at the contact between this and the underlying Gasconade formation, but the fact is of less importance than usual. As stated on page 31 , the shallowing of the seas with its attending phenomena had already begun in the preceding age, and merely attained its full and almost continuous expression in the Roubidoux. As the bottom of the sea could not have been perfectly flat, it is obvious that 
phenomena indicating periodic shoaling and local elevation above sea level must be correspondingly local in their extent. The Roubidoux stands for a condition rather than a time period, and as this condition must have been fully established in some localities a little earlier than it was in others, the lower boundary can not be every. where drawn at precisely the same point. The case is similar with respect to the upper limits of the formation, except that here the phenomena took place in reverse order. Despite these facts, it is believed that the whole area under discussion was so nearly level through the greater part of Potosi time, and especially during this portion of it, that the Roubidoux may be defined and mapped so that it will represent an interval bounded both above and beneath as accurately as it is practicable to measure geologic time.

Considering the conditions under which this formation was deposited, it is to be expected that it would vary considerably in thickness from place to place. The minimum thickness, as reported by Ball and Smith (op. cit., p. 52), occurs near Iberia, where it is said to be only 70 feet thick. In Miller County the thickness ranges from 70 to 160 feet. However, the average thickness for this county, as well as for nearly the whole of the central part of the Ozark area, is between 100 and 125 feet. In local basins along the border of the area, as in the region between Ste. Genevieve and the Jonca granite hills, the thickness of the beds referred to the formation probably exceeds 225 feet.

Concerning the name of the formation, there seems to us to be no chance for reasonable doubt that Nason's Roubidoux, as based on his sections along the Osage and Current rivers, is essentially, if not exactly, the same as the St. Elizabeth formation of Ball and Srnith. The only reason for doubting their equivalence is Nason's erroneous suggestion, subsequently adopted by Winslow, that the Roubidoux is represented in the counties along the Mississippi by the St. Peter ("Crystal City") sandstone. Other synonyms are indicated in the table on page 12 .

\section{JEFFERSON CITY LIMESTONE.}

This formation consists principally of various kinds of dolomitic limestone. Interbedded with these are a few thin beds of sandstone, occurring chiefly in the lower part, thin beds of shale, and even thinner layers of chert. Nodules of concentrically banded, dense chert, most of them conforming with the doubtful organism known as Cryptozoon minnesotense, occur usually in considerable abundance in the residual clays. 'These nodules, which often contain drusy cavities lined with small quartz crystals, are characteristic of the forma- 
tion. The topography of areas in which the Jefferson City limestone outcrops is always less rugged than that of areas in which the two formations next beneath are exposed. Not uncommonly the undulations of the surface are gentle enough in these areas to justify classing them as prairie lands.

The majority of the Jefferson City limestones belong to two varieties, namely, "cotton rock" and medium-grained, massive dolomite. The cotton rock is an argillaceous, siliceous rock, usually containing over 40 per cent of magnesia. It is relatively soft, with a finegrained, earthy or clayey texture and conchoidal fracture. In color it varies from white or yellow to buff and gray. It is nearly always thinly bedded, with the bedding planes even and often exhibiting dendritic markings. Thin shaly partings are common. This variety of stone occurs locally and in limited quantity also in the Roubidoux formation, but the much greater development of cotton rock in the Jefferson City limestone aftords probably the readiest of the criteria employed in distinguishing the two formations. The beds of cotton rock range in thickness from less than a foot to over 30 feet, and they may occur at any horizon in the formation.

On weathering, the surface of the massive dolomite assumes a peculiarly pitted or hackly surface that is sufficiently characteristic to be distinguished from that of the "pitted" dolomites found in lower members of the group.

Chert occurs less abundantly in the Jefferson City limestone than in the preceding formations of the Potosi group. Occasionally beds of brecciated chert occur in association with silicified oolites and sandstone, but these seem to be confined to the lower 100 feet. The Ste. Genevieve copper deposits occur in such a bed. The commonest and at the same time the most characteristic form of chert found in the formation is the "Cryptozoon minnesotense" variety already mentioned.

A number of generally very thin and irregularly distributed beds of sandstone, occurring chiefly in the lower 100 feet, are included in this formation. The thickness of the heaviest of these beds rarely exceeds 5 feet, the others ranging down to 1 inch. Often they contain enough calcareous matter to be called arenaceous limestones. Most of them are medium grained and friable, but here and there one may be found that has been silicified into a hard quartzite. The color is usually a reddish brown, but yellow and white beds are not uncommon. Locally some of the heavier beds contain pebbles of chert and: dolomite.

The Jefferson City limestone is the surface rock over a large portion of the two marginal ranges of counties embraced in whole or in part within the Ozark area. Along the western and southwestern borders of the area and in most of the outliers in these parts of the 
State, the Jefferson City limestone is the youngest of the formations of the Ozark series remaining, the others having been removed prior to the deposition of the Devonian and Carboniferous rocks, which usually rest unconformably on the older series. The St. Peter or First sandstone, and the Joachim or First Magnesian limestone, so far as our observation extends, are wanting in every case where either the Chattanooga shale or one of the basal members of the Boone formation is in contact with the Ozark series. The First sandstone has been seen only in sections containing some later representative of the Ordovician, while the Joachim outcrops only along the eastern border of the area, where the Plattin limestone of the Stones River group is present. Both the First sandstone and the First limestone of the series have been heretofore widely identified in the central and western parts of the Ozark area, but the beds so correlated belong in every case examined to the Jeffer'son City limestone.

The upper beds being absent in the areas where the Jefferson City limestone is at the top of the series, the total original thickness of the formation in such localities can not now be determined. Where it is overlain by the St. Peter sandstone, as it is along the eastern and northeastern portions of the border of the Ozark area, the maximum thickness of the formation probably exceeds 250 feet.

As has been said in the remarks on the Roubidoux formation, the conditions of shallow waters and frequent fluctuations of sea level that prevailed so constantly during the deposition of that variable series of beds gradually gave way to the gentle subsidence that obtained in this age. Shallows still prevailed in the earlier portion of the age, and it is in strata then laid down that a considerable and mostly characteristic fauna is to be found. In the middle and upper parts of the formation, however, fossils are either very rare or wanting entirely. This fact is believed to indicate that subsidence haid progressed to such an extent that the shallow-water organisms of the time became locally extinct.

At the close of the epoch the area was again elevated and, in places at least, sufficiently emerged to be subjected to erosion. The contact with the St. Peter sandstone in such localities is distinctly unconformable.

\section{ST. PETER (" CRYSTAL CITY") SANDSTONE.}

This is the well-known true "Saccharoidal "sandstone. It ontcrops in fine typical exposures at Crystal City and Pacific, at which places it is being worked for glass sand, and at numerous localities in. Ste. Genevieve, Perry, and Cape Girardeau counties. The formation has been so often and so well described that it is unnecessary to give any further description here. It may be worth while, however, to say that in the opinion of the writers the Crystal City, Pacific, 
and Cap-au-Grès sandstones are unquestionably the same formation as the St. Peter sandstone of the upper Mississippi Valley.

Remarks concerning the distribution of this sandstone in Missouri will be found on page 19 .

\section{JOACHIM LIMESTONE.}

This formation rests conformably on the St. Peter sandstone. The contact between the sandstone and the limestone seems, as a rule, not to be sharp, a certain amount of gradation occurring in all cases observed. Above these basal beds the formation usually consists of yellow and buff to light-gray, thinly bedded magnesian limestone, alternating with beds of compact, brittle limestone. Locally thin beds of sandstone, rarely quartzose, are interbedded with the limestones. Fossils have not been observed, except in a single bed occurring about 60 or 70 feet above the base. This is sometimes filled with a species of Isochilina about one-fourth of an inch in length. Surfaces underlain by this formation are commonly marked by large and deep sink holes.

In thickness the Joachim limestone varies greatly. This results from erosion to which the formation was subjected prior to the deposition of the succeeding Ordovician limestones. Except in the counties bordering on the Mississippi River it is absent entirely. Where it was not wholly removed the formation ranges in thickness from a few feet to the maximum of 150 feet reported by Shumard.

The unconformity at the top is often very conspicuous. It is well shown in a long and deep cut on the Illinois Southern Railroad, about 6 miles southwest of Ste. Genevieve. Here an abruptly defined solution channel, having a depth of about 12 feet, is filled with brown and green shales, constituting the basal deposit of the overlying Plattin limestone.

\section{THE ORE DEPOSITS.}

THE STE. GENEVIEVE MINES.

History.-The Ste. Genevieve copper deposits have been described by Frank L. Nicholson. ${ }^{a}$ According to him they were first noted in 1863, though the presence of copper in small amounts seems to have been recognized earlier at the Crow lead mines. Exploration began as early as 1868, the original discovery being followed by the opening in 1876 of the Chicago and Swansea mines and in 1879 of the Herzog. At the time of Nicholson's description the two last named were idle, while the originally discovered mine and the Chicago were being operated under the name of Cornwall mines. At present none of the properties are working.

a Nicholson, F. L., Review of the Ste. Genevieve copper deposits: Trans. Am. Inst. Min. Eng., vol. 10, 1882, pp. 444-456. 


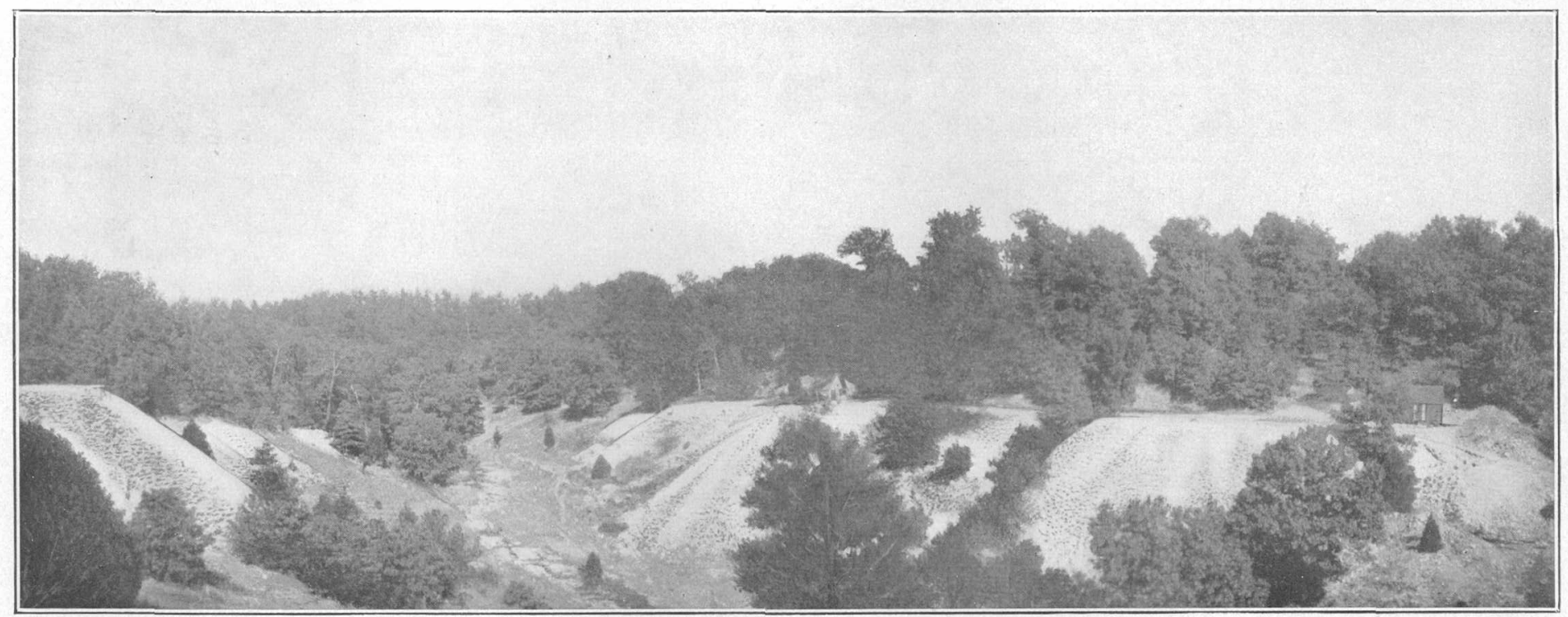

WORKINGS OF THE CORNWALL MINE, STE. GENEVIEVE COUNTY, 
There are no data available for a complete estimate of the production, but in the Tenth Census ${ }^{a}$ these mines are credited with an output for the census year of 230,717 pounds, valued at $\$ 25,730$. As they were operated more or less actively for nearly a quarter of a century their aggregate production presumably has been considerable.

Geology.-The copper mines are situated about 8 miles southwest of the town of Ste. Genevieve, in sections 15, 16, 21, and 22 of T. 37 N., R. 8 W., along a small stream tributary to the Aux Vases River. The ore occurs principally at two horizons 125 feet apart, in the lower part of the Jefferson City limestone. The workings along the main horizon are shown in the photograph forming Pl. I. The country rock is a coarse magnesian limestone with numerous flint nodules. 'These are ordinarily from 2 to 4 inches in diameter, and are arranged in horizontal bands along bedding planes. They are the clear white to blue flints, such as are common in the Mississippi Valley, and do not show the druses which characterize the flints of the Gasconade formation. Certain thin and irregular sandstones are interbedded with the limestone. A very hard, quartzose bed, about 2 feet thick, occurs 15 to 20 feet beneath the main ore body at the Cornwall mines.

Faulting of some magnitude occurs in the region, and there is some evidence of faulting near, but not at the mines. The beds are practically horizontal, though there is a slight dip toward the northeast. In the general region there are outcrops of underlying preCambrian crystalline rocks, though none of these are known at the mines. No other igneous rocks are found in the area. Topographically the region is a dissected plateau of some roughness.

Ore bodies.-At the Cornwall mines the ore occurs, as stated, at two horizons, of which the upper has been mainly worked. A third horizon still higher in the hill and, so far as known, not economically important, is reported by Dr. E. D. Peters. Both horizons worked are above local water level. Workings in the lower bed are mainly closed and the upper only was especially investigated. The workings extend along the edge of a horizontal bedded breccia completely around the head of the small valley in which the furnace is located. Drifts have been run into the hill at intervals, and room-and-pillar workings opened-much like those of a coal mine. No map of the workings is available for reproduction; but there are a good many hundred feet of drifts now open, and a number of excellent faces of ore may be seen.

The ore bed is from 18 inches to 3 feet thick in most parts of the mine. It seems to be thickest at the intersection of the breccia and certain small vertical fractures, along which chimneys of ore are formed, extending upward as much as 16 feet above the usual base. 
The ore also goes down at such intersections, but seemingly not to any important extent. It consists now of a breccia of white flint, cemented mainly by chalcopyrite, but with malachite, azurite, limonite, and calcite present. Galena is reported to occur occasionally in small druses, but was not seen. Cuprite, chalcocite, tenorite, etc., occur in subordinate amounts. 'The cap rock and the floor of the workings consist of ordinary magnesian limestone.

An examination of the freshest specimens of the ore brings out the following details: The chalcopyrite, now very finely brecciated and in part cemented by "brown copper," is itself the matrix for fragments of white chert. This chert exists now in two forms, (1) a clear, fresh, almost glassy material, similar to the usual chert of the surrounding country, and (2) an earthy granular material known to the miners as "chalk." A microscopic examination of the latter by Mr. Lindgren shows that it is composed mainly of finely divided quartz, with some sericite. This confirms the impression, based on macroscopic examination, that it represents an alteration form of ordinary chert in which a portion of the silica has been removed by solution. Pari passu with this change has occurred the substitution of copper carbonate, and even in a single hand specimen all stages of the process can be observed, from the introduction of malachite along the cracks and the clouding of the clear chert to the complete substitution of the bright-green mineral for the sharp-angled white fragments. At the same time the brassy yellow chalcopyrite has been finely broken up and altered to the somewhat indefinite mixture known as "brown copper." It would seem, therefore, that the formation of malachite and other oxidation products marks a recent change, characterized by a tendency toward replacement of the silica. The introduction of the sulphides was evidently earlier and apparently the work of waters having other sources, since they were of such composition as to leave the chert unattacked even in small sharpangled fragments. Presumably these sulphides replaced the dolomite in which the chert was originally bedded or were deposited in the interstices of the breccia, but as to this and the origin of the chert itself there are at present no certain data.

In the lower horizon the Revere tunnel, now partly closed, shows copper pyrites disseminated through a bed of coarse granular dolomite. There does not seem to be here any chert breccia, though the ore appears to be bedded. So small a portion of the work is open, however, that no very certain conclusions can be drawn. The bed is said to be rich, but of small extent.

Value of the deposits. - No attempt was made to sample the mine. Considerable ore is said to have been shipped, running 20 to 27 per cent in copper, and the old dump is estimated to contain 5 per cent of metal. A 16 per cent grade is said to have been commonly produced. 
'These claims, in the light of the appearance of the ore in the mine, do not seem extravagant. Faces of workable ore are certainly now open.

Drilling by Mr. Doak, a former owner, is reported to have shown three additional copper horizons at lower depths, and also to have shown something as to the extent of the ore body into the hill. The - records of this drilling are not at hand. Dr. E. D. Peters states that 8 to 10 churn-drill holes put down under his direction several hundred feet apart and covering an area extending 1,800 feet eastward from the present workings all showed copper at the horizon of the main chert breccia. In the case of flat-lying, bedded deposits near the surface drilling is a very effective and cheap method of. proving the extent of an ore body. The method is especially well suited to these deposits.

At the time the mine was working no railway was near enough to be of service, and all freight had to be hauled by wagon approximately 10 miles from the steamboat landing above Ste. Genevieve. Recently the Illinois Southern Railway has been built within $2 \frac{1}{2}$ miles of the mine. This line affords a direct and short route to the Illinois coal fields and materially affects the working conditions. It is quite probable that well-considered effort would result.in a small, but profitable, copper industry.

\section{MINE LA MOTTE.}

This famous property includes some of the oldest mines in the United States, and up to $1893 \mathrm{Mr}$. Winslow estimates that it had produced approximately $\$ 10,000,000$ worth of lead alone. In addition, copper, nickel, and cobalt occur and have been sold in quantity. At present the old copper mines are being reopened and other changes made in the operation of the property. In 1904 approximately 55 tons of metallic copper were produced in matte and ore. It is expected that in the future this product will be larger.

No extensive study of these mines was made in the course of the present investigation and no general account of the property will be given. The mines were visited, however, and the following notes are given for the sake of their bearing on the general problem of copper in this area. The history of the mines has been so completely summarized by $\mathrm{Mr}$. Winslow " that it is not necessary to discuss it.

The mines are located in Madison County, east of the main St. Francis Mountains, and among some outlying knobs of granite and porphyry. The ore bodies are typical disseminated deposits originating by metasomatic replacement of the dolomite. They occur near the base of the Bonneterre limestone and principally in or near certain

\footnotetext{
"Winslow, Arthur, Lead and ninc deposits: Missouri Geol. Survey, vol. (i, 1894, pp. $267-302$; vol. 7,1894 , pp. $646-659$.
} 
shaly beds in which Lingulella and other forms occur: Copper pyrites with sulphides of nickel and cobalt are found constantly in connection with the lead and are mainly separated at the dressing works.

In the southwestern part of the estate is a property long known as the "Copper mine" and now being reopened by the Mine La Motte Development Company, a corporation holding a lease from the main La Motte company. The copper mine is located on the flank of a small porphyry hill and the ore occurs in the Bonneterre limestone near its base. The dolomite is dark colored, shaly, and includes small porphyry pebbles. The mine was originally opened some seventy-five years ago by means of an open pit, from the back of which an adit was driven in along the bed. The old drifts had not yet been cleaned up when visited and were badly caved. In the rooms opened along this adit the sulphides were seen disseminated through approximately 10 feet of the dolomite. Galena, pyrite, and chalcopyrite occur together, thoroughly disseminated through the rock. In one part of the mine the copper pyrite, with some dark mineral, probably chalcocite, was seen segregated in a distinct bed, 3 to 10 inches thick, toward the base of the deposit as a whole, and yet above the most important bed of galena. This copper bed seems to have been the one mainly taken out when the mine was formerly worked. The galena below is largely undisturbed.

The strata throughout the mine roll slightly and irregularly, these rolls being very similar to those common in coal mines, whereby separate irregular basins are marked out. In this case the irregularities very probably reflect the irregularities of the sea bottom upon which the beds were laid down.

The occurrence of copper in this mine as a sulphide is interesting because of its intimate relations to the great disseminated lead deposits of the region. Any explanation of the genesis of the one must take into account the presence of the other, and no attempt will be made at present to discuss this large subject.

South of Fredericktown and at several other points in the vicinity copper is found. ${ }^{a}$ None of these prospects are now open. So far as is known the occurrences are similar to that at Mine La Motte.

\section{SHANNON COUNTY MINES.}

Location.-In Shannon County there are showings of copper, and attempts have been made to mine at eight localities, which are indicated on the accompanying map (fig. 2). The largest amount of development work has been done at the Slater and so-called Jerktail properties. None of the prospects are now being developed. They are all within a few miles of Eminence, the county seat. Eminence

a Keyes, C. R., Mine La Motte-sheet: Missouri Geol. Survey, vol. 9, 1895, p. 79. 
is connected by daily stage with Winona, on the Current River division of the.Frisco system.

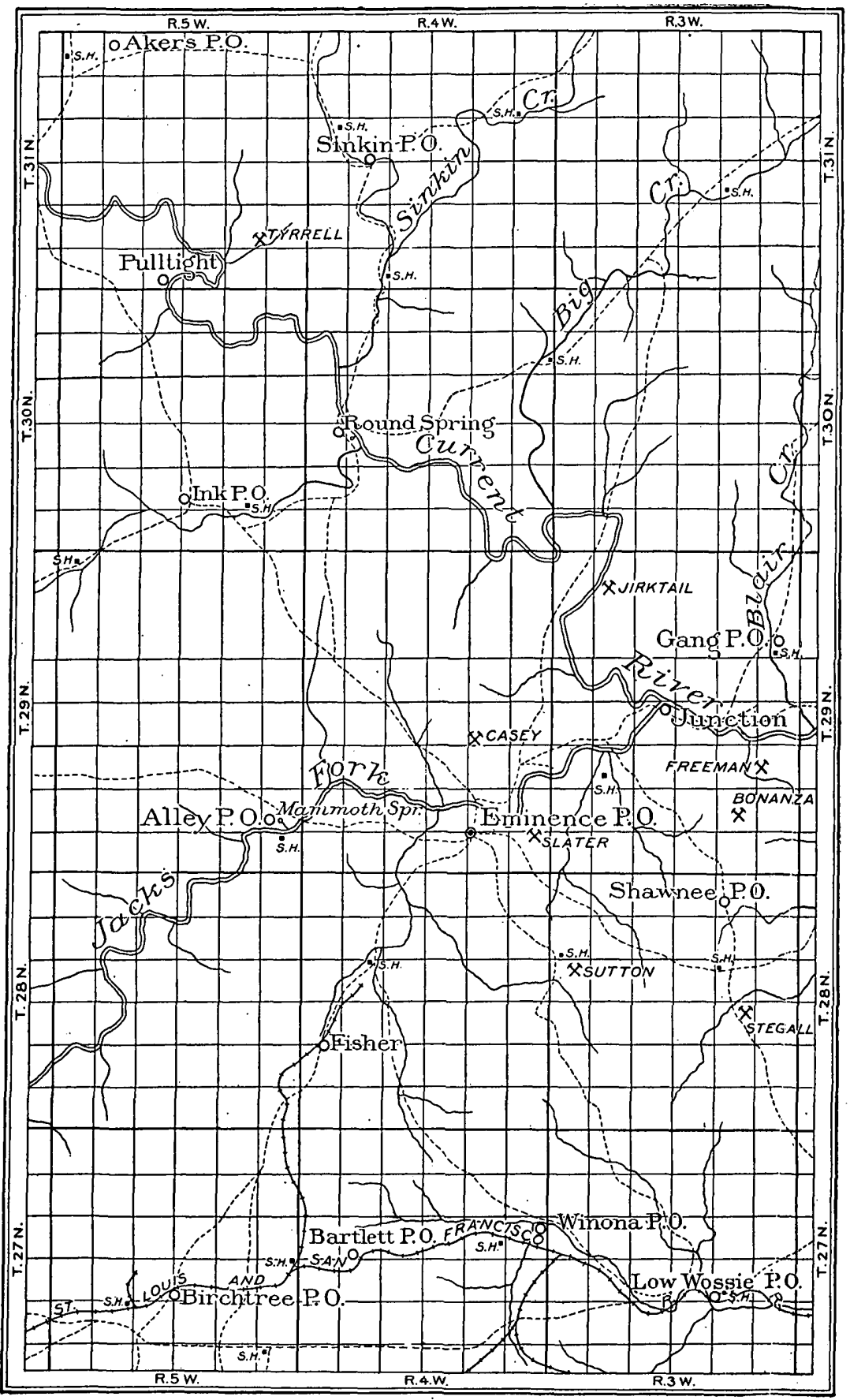

Fra. 2.-Sketch map showing occurrences of copper it Shannon County. 
History.--The first attempt to regularly mine copper in Missouri seems to have been made in Shannon County some sixty-five years ago, when the Slater mine attracted attention. The following historical notes were compiled by J. H. Hahn, of Winona, Mo., and by him placed at our disposal. They represent the best obtainable information regarding this interesting property.

In 1837 , when Shannon County was practically a wilderness, 150 miles from a railroad, the French settlers at Ste. Genevieve, Mo., imong whom were the Valles and Henry Janis, sent Joseph Slater, an experienced miner, to develop the copper deposits of Shannon County, which locality at thit time was composed largely of unsurveyed Government lands. Slater bought the possessory right of one George Smith, a bunter, who hatd discovered the copper; and, after erecting a small blast furnace of stone, he mined and smelted about $\$ 50,000$ worth of copper.

In 1840 the lands of that locality were surveyed by the Government; whereupon a speculator by the name of. John Epps Cowan preempted the land, completely ousting Slater, but not without a legal contest which was carried to the tribunal of last resort. Cowan sold the mine to other speculators in the East, who, thinking the property too remote from market to be successfully worked, closed it down.

The mine remained idle until the year 1876 , when one Charles T. Biser, of St. Louis, having purchased many thousand acres of other lands in Shannon County, hunted up the owners of the mine and acquired the title to that tract. After: mining and shipping a few carloads of copper, Biser sold all his holdings to the Current River Land and Cattle Company, a corporation composed of Michigan capitalists who take no interest in mining.

For twenty-five years the Slater again lay idle, when attention was called to same by F. M. Rogers, a mining prospector from Colorado. Mr. Rogers obtained a 99-year lease on the mine, which is now owned by the Slater Copper Mine Company, a corporation of Winona, Mo.

When a land survey of this area was made, the occurrence of copper was noted at a number of points and indicated upon the usual township plats. On the sectional map of the State, first published in 1865 by John T. Fiala, and revised and republished in 1881 by Campbell, the various copper localities are marked by symbols. About a half dozen are indicated in Tps. 28 and 29, Rs. 3 and 4 W. This map was compiled from all available data, and includes everything given on the Land Office map of 1811.

Bibliography.-The literature relating to the field is very limited. Below is an abstract of the important papers:

[Hodge, Tas. T., Wisconsin and Missouri lead region: Am. Jour. Sci., 1st ser., vol. 43, 1842, pp. 65-72.]

Deposits found along contact of a red porphyry with a limestone. No regular contact. Fissiures between the two rocks filled with iron ore, copper ore, clay, and gossan. Little veins of copper ore in limestone. Ores are malachite, cuprite (?), and chalcopyrite. The "rotten vein" between the two rocks is a breccia of both with particles of malachite scattered through it. Ore is mined at three localities. In one the ore is more sulphide than carbonate, and the latter is partly azurite. 
1. Whitney, J. D., Metallic Wealth of the United States, 1s54, 1. 311.1

No mining worthy of nalue. Deposits on contact between Lower silurian limestone and Archean quintz-porphyry. Not likely to be profitible.

[Report of the Current River Mining Company, accompanying charter and by-laws of the Current River Mining Company, of Missouri, by Stephen Bawden, mine agent, New York, 1854.]

'The vein is of promising character, being composed of "gossin spar" and sulphuret of copper, green carbonates, and malachites. The lode is embedded in red granite or porphyry. 'T'he mine has a regular or true vein with a dip. of $1 \frac{1}{2}$ feet to the fithom, running northeast-southwest. There are probably other parallel veins.

[Broadhead, G. C., Rept. Missouri Geol. Survey, 1873-74, chap. 5, p. 48.]

No copper mining now done. Mining formerly carried on in five counties. Copper ore noted in twelve others. Ores are arurite, malachite, and clialcopyrite.

[.Nason, F. L., Report: on iron ores : Missouri Geol. Survey, vol. 2, 1892, p. 95.]

Chalcopyrite mined to some extent near Sminence, in Shamon County. Exiact locality not reported.

I Winslow, A., Geology and mineral products of Missouri: Missouri at the World's Fair [at Chicago], 1893.]

The principal occurrences of such (copper) ore are in Ste. Genevieve, Shannon, and Franklin counties. Found in magnesian limestones of Cambrian age.

[. Haworth, Erasmus, Crystalline rocks of Missouri: Missouri.Geol. Survey, vol. S, 1894, p. 207.]

The porpbyry in Shannon County is very similar to that northeast. Portions are the ordinary red kind. Other portions are filled with the light-gray or light-green feldspar phenocrysts, which are common to the northeast.

Slater mine.-The Slater mine is about 2 miles east of Eminence, at a point where one of the common porphyry ridges of the district projects through the Gasconade or Cambro-Ordovician dolomites. The particular knoll, on the east versant of which the copper occurs, is one of a chain extending for several miles in a northwest-southeast course. The porphyry is the usual red type so common in southeastern Missouri. It is of pre-Cambrian age. Separated from it by a marked unconformity are the gently dipping granular dolomites of the Gasconade formation. The cherty dolomites and sandstones of the Roubidoux formation occur in the higher hills surrounding the exposure.

The contact between the porphyry and the limestone is in an irregular plane, dipping at a low angle to the east. It is occupied by a well-developed conglomerate in which there are bowlders and pebbles of porphyry in a matrix of coarse crystalline dolomite. This conglomerate is not now exposed in its full thickness, but old workings are said to have shown a total of 12 feet. At the particular point at which the copper is found the surface of the porphyry dips 
down, forming a shallow basin or cove, in which the conglomerate was laid down.

Copper in the form of chalcopyrite $\left(\mathrm{CuFeS}_{2}\right)$ and the green carbonate, malachite $\left(\mathrm{CuOH}_{2} \mathrm{CO}_{3}\right)$, occurs in the matrix of this conglomerate. The chalcopyrite forms small, irregular crystals and grains varying in diameter from 1 millimeter to a half inch. They occur with rhombohedral crystals of dolomite of nearly uniform size and grains of quartz in a paste of greenish clay. The carbonate is found in similar disseminated grains, apparently the altered remnants of chalcopyrite, and also in flecks and thin seams penetrating and replacing the porphyry fragments. At the surface, where the rock has been exposed, the cracks and crevices contain a black, sooty powder, apparently mainly manganese oxide, bearing copper probably in the form of the oxide or of chalcocite $\left(\mathrm{Cu}_{2} \mathrm{~S}\right)$. An assay of this material in the Survey laboratory, by George Steiger, gave 6.44 per cent copper.

The largest amount of work done on the property has evidently been in the stripping and mining of this conglomerate over some 3 acres. To the east, where the rock dips under cover; it has not been followed. Along the strike less prominent copper showings are said to occur at intervals for nearly 2 miles.

Copper also occurs in the porphyry, and several shafts have been sunk, following small veins into this rock. One of these shafts is reported to be 160 feet deep. This was filled with water at the time the property was examined. The rock on the dump showed thin seams in the porphyry, and in these small crystals of quartz, dolomite, and chalcopyrite occur. In no specimen seen was the amount of the latter sufficient to make the rock workable. In other pits not so deep similar crevices in the porphyry were seen filled with the green carbonate. This occurred at one place as mach as 4 inches thick and practically free from admixture with other minerals. All the crevices examined were small, an inch or two in width at most, and all have a general northwest-southeast course, parallel to the general trend of the porphyry hill. They are not larger, more numerous, or, except for their content of copper, more impressive than at many other points in the porphyry of the region. Several of the earlier observers have mentioned "true fissure veins" as occurring in the porphyry, but so far as observations of the present writers go these minor crevices are the only foundation for such statements.

The prospective value of the property is so intimately connected with the probable genesis of the ores that it is necessary to consider at least the possible character of the latter.

The chalcopyrite is not apparently present in quantities of economic importance; the question of the origin of the sulphides is therefore relatively unimportant. It is believed that they were 
derived from the porphyry by leaching either (1) of minutely disseminated quantities of copper, known to be present in the rock, or (2) of small veins locally present, of which the ores now exposed are representatives. This is believed to have occurred at the time the conglomerate was formed, though it is quite possible that the process continued in operation through later geologic ages.

The carbonates, oxides, and possible chalcocite present are alteration products from the sulphides, and the topographic and structural features of the deposits indicate clearly that this alteration has been accompanied by at least some concentration. The open, porous conglomerate affords abundant opportunity for the circulation of waters, while the decomposition of the lime-soda feldspars of the porphyry fragments would serve to precipitate as carbonate any copper sulphate present. It is notable that the decomposed porphyry pebbles and the carbonate are closely associated. In any such process the carbonates would be carried down, more or less, and precipitated in the upper fissured part of the porphyry below, and this is believed to have been the origin of the carbonate found in that situation.

It follows from the above considerations that future prospecting should be directed toward finding extensions of the conglomerate and points of local enrichment rather than toward following the small veins into the underlying porphyry. The cove in which the deposits occur opens out to the east, in which direction also the rocks dip. A series of drill holes parallel to the outcropping edge of the conglomerate should determine the depth and extent of mineralization very cheaply.

Jerktail mine.-This is one of the older and better-known prospects. It is said to have been worked about 1840 and again in 1870, and shipments have been made from the property. There has been some recent prospecting. There are several shallow shafts and one drift. The conditions are very similar to those at the Slater mine. The Gasconade limestone rests on the porphyry with gently sloping contact, and the usual conglomerate is present. In this conglomerate both chalcopyrite and malachite occur, and there has evidently been some reconcentration of material. There is the same pre-Cambrian erosion basin or cove, in this case fronting to the southwest rather than east, and the geologic and topographic features of the two localities are almost identical. One exception is that present exposures at least do not show small veins running down into the porphyry, as observed at the Slater mine. There are no sufficient data for estimating the probable size and value of the deposit.

Sutton mine.-This property, 5 miles southeast of Eminence, resembles the Slater and Jerktail, in that copper carbonate is found in the base of the liniestone at the contact with the underlying porphyry. 
There are no recent openings, and the details of the occurrence are not so well displayed as at the other mines mentioned, but the phenomena seem to be essentially the same.

Casey mine.-About 2 miles north of Eminence, in a saddle between high flint-capped hills, copper has been found in the limestone and away from any immediate contact with porphyry. The horizon is in either the basal portion of the Roubidoux or near the top of the Gasconade limestone, and is thus considerably above that of the copper at the Slater mine. The country rock is a coarse, granular dolomite, in which is a bed of shale 4 to 12 inches in thickness. In this shale, and at points completely replacing it, is copper, mainly in the form of malachite, but also occurring as chalcocite. The bed has been followed into the hill by means of an adit some 50 feet. A few years ago the property came into the hands of certain Pittsburg people, who abandoned the drift and began sinking. It is said that they have discovered a second, but seemingly less extensive, copper horizon below the ore worked in the drift.

The rocks are horizontal, bedded limestones, with no signs of faulting or of vein phenomena. There are no outcrops of porphyry in the immediate vicinity. The origin of the copper is somewhat more difficult of explanation than at the Slater mine. It can only be said that copper-bearing solutions have evidently circulated somewhat extensively through the rocks of the region, and that the shale band has afforded a favorable horizon for its lodgment, either by direct reduction through the action of organic matter or by the mechanical process recently described as adsorption.

The extent of the deposits is unknown, owing to the way the prospecting has been carried on. They do not seem likely to be large.

T'yrell mine.-At this property, which was visited by Mr. Ellis, the copper occurs in the form of chalcocite and malachite in a brecciated dolomite, resembling in hand specimens some of the material found at Ste. Genevieve. So far, however, flats have not been developed, all the ore mined having come from a small vertical seam running northwest-southeast. This has been followed down 48 feet, and is said to have shown some copper the whole distance. The slope above the prospect is covered with chert and sandstone, probably betokening the presence of the Roubidoux, so that the horizon is probably about the same as at the Casey mine.

Bonana prospect.-Situated about 6 miles east of Eminence, this is instanced as typical of a number of small prospects scattered throughout the county. Not far from a porphyry outcrop, but in the limestone hill above it, a few small pits have been sunk. Apparently they merely reached the solid rock. No copper minerals of any lind are now shown on the dumps. A green mineral in small flakes, probably chlorite, has apparently been mistaken for malachite. 
In the porphyry at the foot of the hill are some thin streaks of white quartz; and at the contact of the porphyry and the limestone a black earthy material is found in small quantity. This not improbably contains some chalcocite, since it is said to show on assay 4 per cent of copper and 1 ounce of silver per ton.

Freeman prospect:- This is very similar to the Bonanza. Copper carbonate and galena are said to have been found in small quantity in shallow pits in the limestone. At present nothing but ordinary limonite and residual clay are exposed.

General conclusions.-From the descriptions already given of the individual prospects it will be evident that there is small probability of true vein deposits of value being found in the porphyry. The largest amounts of copper are in the limestone, and of the two horizons recognized the lower is the more favorable. Along this, where the structural and topographic conditions have been favorable, copper occurs in the conglomerate. The deposits are thus essentially blanket veins, and in view of their.shallow dip they may be most easily prospected by drilling and test pitting. Such ore as occurs is of a nature to be easily reduced, and the samples seen are evidently of good grade. The size of the ore bodies can be determined only by additional prospecting.

\section{THE SULLIVAN MINES.}

History.-On the northeast flank of the Ozark uplift, in Franklin, Crawford, Phelps, and adjacent counties, copper minerals have been found at a number of points, and several attempts have been made to develop mines. Recently some prospecting has been carried on near St. James, Phelps County, and the Missouri Copper Mountain Mining Company has put in operation a 20 -ton furnace near Sullivan, on the Frisco system. This corporation, composed largely of persons living at Sedalia, Mo., owns nearly 7,500 acres of land in Washington and Crawford counties. Development has been under way for nearly three years, an attempt having first becn made to concentrate and ship the ores and later a furnace having been built and put in operation. The works are located in sec. 24, T. $40 \mathrm{~N}$., R. 2 W., in Crawford County. They are at the old Sullivan and Bridell mine, where the Hamilton Iron Company, up to 1873 , took out specular iron ore.

Goology.-The area in which the copper has been found is that known in the older geologic reports as the region of the "Second sandstone." Nason used "Roubidoux sandstone" to designate the surface rock of the district, and applied Gasconade limestone ${ }^{a}$ to the heavy limestone beds found in the lower portions of the valleys.

a Nason, F. L., Report on iron ores: Missouri Geol. Survey, vol. 2, 1892, p. 114. 
The ore is found in residual clays, filling pits in the Gasconade limestone and near the outcropping edge of the overlying Roubidoux.

The copper occurs in connection with or near to the specular ironore deposits which characterize the district. These iron deposits have been described by Nason, ${ }^{a}$ who considered them to represent concentrations made by surface waters in sink holes. He noted the common association with the hematite of sulphides of iron, copper, lead, zinc, and arsenic, and the fact that these sulphides occur most abundantly at the bottom of the deposits. Indeed, he considered the iron to have been originally concentrated as a sulphide, and to have been later altered to hematite. This theory of the origin of the ores would make them strikingly analogous to the iron cappings, or gossan, over mixed sulphide ore bodies, such as occur in the Western States.

In 1904 a number of the old iron pits of this area were reexamined and Nason's observations were confirmed. It was found very commonly that sulphides and carbonates of copper, in particular, occur in intimate mixture with the hematite at the bottom of the now abandoned pits. How important in amount this ore may be was not determined, but its widespread occurrence was very evident and its position is believed to be significant.

Ore bodies.-The copper mined at Sullivan is obtained from shallow workings on the side of a hill, near the top of which iron was formerly mined. The old iron pits are now partially filled by surface wash. The ore body was evidently of the usual.irregular form, and the ore now remaining in the bottom of the pit and in the short drifts running back into the hill is low grade and siliceous. The dump shows the usual red hematite and ocher. Copper is reported to have been found in the lowest part of the old workings, but none is now exposed.

Lower on the slope are the shafts recently sunk in search of copper. The dumps around these shafts show red hematite, broken and brecciated, and with thin flakes and seams of copper carbonate running through it. The surface is mainly covered with red clay and chert fragments, though limestone and sandstone are also present. On the dumps are pieces of a dark-colored limestone which shows veins of calcite one-sixteenth to one-eighth inch thick, with similar but still thinner veins of pyrite, which also occurs in very fine-grained, irregular particles through the rock. Portions of the limestone have been altered to a brown, vitreous, porous rock, greatly resembling garnet in appearance. Under the microscope it is seen to be now composed almost wholly of crystalline quartz with occasional small aggregates of malachite. Running through the quartz, without re-

a Nason, F. L., Report on iron ores: Missouri Geol. Survey, vol. 2, 1892, pp. 116-157. 
gard to the crystal boundaries, are irregular convoluted bands of brown iron oxide. Apparently these ontline the grains of the original limestone, now wholly replaced by silica.

The main workings are below these shafts, the entrance being by adit connected with one of them. The adit. is cut through a bar of limestone, beyond which is a body of soft red clay, in which the copper occurs. Both chalcopyrite and the usual alteration products occur, irregularly distributed through the clay. Balls of the chalcopyrite a half foot or more in diameter and coated with malachite and chalcocite are found. Not enough work has yet been done to develop the form of the ore body, but it is known to be somewhat irregular. Both lead and zinc ores occur on the same land, though neither were seen in the copper workings.

It would seem that the copper occurs in a residual clay occupying an irregular pit in the limestone of the hillside. It is above water level and below the main body of iron ore. It was oxiginally in the form of a sulphide, and the present ore has resulted in part from concentration in situ by residual action. Probably also copper has been leached out of the higher portion of the hill, the iron being left behind as a gossan. Accompanying this action there has been at least local silicification of the limestone. The original introduction of the sulphides was by waters which were of different composition, since for a long time the waters of the region have been destroying rather than building up the sulphides. The nature and source of these waters are for the present uncertain. So far as known, the original sulphides are not sufficiently rich to be worked alone for copper, and only the pockets found in the coves of residual reconcentration warrant prospecting.

Value of the deposits.-No general sampling of the mine was attempted. An average sample of the face of one drift, as nearly as it could be taken, was found, on assay in the Survey laboratory by George Steiger, to carry 12.55 per cent of copper. It is impossible to say what the average of the whole ore body would run. It is estimated by H. H. Graham, manager of the property, that the ore going to the furnace runs 5 to 8 per cent. From a twenty-day run in 190430,000 pounds of pig copper and matte resulted. This is equivalent to 22,500 pounds of metallic copper. A According to the records of W. H. H. Myers, secretary of the company, the ore used in the furnace during this run averaged 14 per cent. The ore is practically self-fluxing and easily and cheaply handled. So long as no greater difficulties than those now apparent arise, it should be possible to work this ore profitably. In view, however, of the very great irregularities in form and richness characteristic of residual ores, it is impossible to make any valid estimates for the future.

Bull. $267-05 \mathrm{M}-4$ 


\section{GENERAL SUMMARY AND CONCLUSIONS.}

Copper in the form of sulphides and carbonates has been found at many points in southern Missouri and has been mined in several localities, notably in Ste. Genevieve, Madison, Shannon, and Crawford counties. Very large deposits, rivaling those of the West, have not been found and are not to be expected. The character of the ore and the low cost of flux, fuel, and labor make it possible to work some, at least, of the deposits with profit.

The ores show a preference for certain stratigraphic horizons, and, being bedded, may be prospected with ease and economy. The common association of sulphides with specular iron of the sandstone region points to the advisability of the investigation of the old iron pits. While any copper deposits found will probably not be large, they should be easily and cheaply mined. In Shannon County the most favorable localities are along the contact of porphyry and dolomite at points where the conglomerate beds at the base of the latter fill in shallow basins in the crystalline rocks. In the disseminated lead district of southeastern Missouri copper occurs in connection with the lead, and at a few points can be saved to advantage.

The ores were doubtless formed by concentration of material originally disseminated in the surrounding rocks. Winslow andRobertson ${ }^{a}$ some time since proved that both the crystalline rocks and the dolomites of this region contain copper in minute but sufficient amounts. The preference of the ore bodies for certain horizons is believed to be dependent mainly upon original unequal distribution of material resulting from land and sea conditions at the time the rocks were laid down. Excepting the Mine La Motte deposits, all the important copper deposits of Missouri are found in that part of the Potosi rocks which was laid down in shallow waters and when frequent changes of shore line were evidently occurring. The Ste. Genevieve deposit occurs in brecciated horizontal chert in the lower part of the Jefferson City limestone; the Sullivan deposit has been segregated from beds near, probably just beneath, the Roubidoux sandstone; and in the Casey mine the ore is found in the Roubidoux. The Slater, Jerktail, and Sutton mines, in Shannon County, occur along the contact between old porphyry islands and the dolomites of the Gasconade formation. The Mine La Motte ores occur where the similar Bonneterre limestone laps upon similar porphyry hills. Everywhere the distribution of the copper seems related to original shallow-water conditions. At some later period in the course of the work of underground waters this originally disseminated copper. was segregated in the bodies now found.

a Winslow, Arthur, and Robertson, J. D., Leạd ạnḍ ẓinc deposits: Mișsouri Geol, Surrey, vol. 7,1894 , pp. $479-480$. 


\section{N D E X .}

Acadian rocks, occurrence and character of.

Adams, G. I., on Missouri geology......... Archean rocks, occurrence of ............. Bain, H. Foster, work of . . . . . . . . . . . . Ball, S. H., and Smith, A. F., on Missouri rocks

on Roubidoux formation............ 31,33

Barite, occurrence of .................. 10

Billingsella sp., occurrence of........... 22

Biser, C. T., copper shipped by ......... 9,42

Bolin Creek sandstone member, correlation of . . . . . . . . . . . . .

Bonanza prospect, description of . . ...... 46-47

Bonneterre.limestone, copper in ...... 39-40,50 occurrence and character of ..... 12,17, 21-23 section of $\ldots \ldots \ldots \ldots . . . \ldots . \ldots . .25$

Broadhead, G. C., on Ozark series ........ 13

Cambrian rocks, occurrence and character

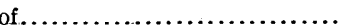

Camden County, graphic granite in ........ Camp Cole sandstone. See Gasconade limestone.

Cap-au-Grès sandstone. See St. Peter sandstone.

Casey mine, description of ............46,50

Chicago mine, opening of ............ $\quad 36$

Cobalt, occurrence of................ 9,39

Copper deposits, character of............ 50

descriptions of .................... 36-49

distribution of . .................. 10-11

location of, maps showing........... 11, 41

mining of, history of $\ldots \ldots \ldots \ldots \ldots \ldots \ldots .9-10$

origin of ......................... 50

production of ore from $\ldots \ldots \ldots \ldots \ldots \ldots, 39$

value of .................... 38-39,49-50

Cornwall mine, account of . ............ $36-39$

workings of, plate showing ......... 36

Cowan, J. E., sale by .................... $\quad 42$

Crawford County, copper in..........47, 50 smelting in .................... 9

Cryptozoonminnesotensis, occurrenceof. 30,33-34

Crystal City sandstone. See St. Peter sand. stone.

Decaturville limestone. See Bonneterre limestone.

Doak, —, drilling by ................ 39

Ellis, E. E., work of . ............... 9

Elvins, sections near ................ 24-25

Elvins formation, occurrence and character of . . . . . . . .

section of $\ldots \ldots \ldots \ldots \ldots \ldots \ldots \ldots \ldots \ldots \ldots \ldots \ldots \ldots .24-25$

Eminence, copper near.........40-41,43,45-46
Page.

Fiala, J. T., map published by

42

Finley limestone. See. Jefferson City limestone.

First Magnesian limestone. See Joachuim limestone.

First sandstone. See St. Peter standstone.

Folley limestone. See Joachuim limestone.

Fossils, evidence from ............... 20

occurrence of .............. 22, 28, 30,32,36

Fourth Magnesian limestone. See Gasconade limestone; Bonneterre limestone.

Franklin County, copper in ........... 47

Frederick town, copper near............ 40

Freeman prospect, description of ........ 47

Gasconade limestone, copper in........ 46,50

occurrence and character of ......... 12,

$14-18,28-31,43,47-48$

stratigraphic limits of ............... 28

Geology of Ozark uplift ................ 13-36

Graham, H. H., estimate by............

Gunter sandstone. See Gasconade limestone.

Hahn, J. H., on Shannon County mines ...

Hayes, C. W., letter of transmittal by...... 7

Helicotoma sp., occurrence of........... 32

Herzog mińe, opening of..\........... 36

Iron, occurrence of . .............. 10,48

Iron Mountain conglomerate. See Pilot Knob conglomerate.

Isochilina, occurrence of .............. 36

Jefferson City limestone, copper in ....... 37, 50

occurrence and character of .. 12,14-16,33-35

Jerktail mine, description of ..........45,50

Joachuim limestone, occurrence and character of $\ldots \ldots \ldots \ldots \ldots \ldots \ldots \ldots 12,16,36$

Joplin district, copper in.............. 11

Key sandstone. See St. Peter sandstone.

Keyes, C. R., on Missouri rocks ....... 12, 16-17

La Motte sandstone, occurrence and character of ............ 12, 16-17, 2()-21

Ladd, G. E., on copper production ....... 10

Lead, occurrence of ................. 10 production of ...................... $\quad 39$

Lesueur limestone. . See Gasconade limestone.

Lindgren, Waldemar, on Ste. Genevievo ores...................... 38

Lingulella, occurrence of............. $\quad 40$

Lingulepis Jambornei, occurrence of...... $\quad 22$

Madison County, mines of.............. 39,50

Magnesian series, formations of, classification of, attempts at........... 13-2C 
Magnesian series, formations of, classification of, table showing..........

Manganese, occurrence of.

Map showing locations of copper deposits in Missouri...

Map showing locations of copper deposits in Shannon County

Marshfield limestone. See Jefferson City limestone; Roubidoux formation.

Mine La Motte, copper from description of

production of $. . . \ldots \ldots \ldots \ldots \ldots \ldots \ldots . .$.

Mine La Motte Development Co., work of..

Missouri Copper Mountain Mining Co., smelter of ............... 9-10,47

Moreau sandstone. See Roubidoux formation.

Myers, W: H. H., information from

Nason, Frank L., Gasconade limestone named by

on Magnesian series. $12,14-15,17$

Nicholson, F. L., on Ste. Genevieve mines.. 36

Nickel, occurrence of ................. 9,39

Ordovician rocks, occurrence and character of ........................ 12

Ore deposits, occurrence and character of . 36-50 Osage limestone. See Gusconade limestone.

Ozark series. See Magnesian serjes.

Ozark uplift, copper in, occurrence of...... 10 geology of $\ldots \ldots \ldots \ldots \ldots \ldots \ldots \ldots \ldots \ldots, 10-36$

location of $\ldots \ldots \ldots \ldots \ldots \ldots \ldots \ldots \ldots \ldots . \quad 10$

Ozarkia, location of .................... 14

Pacific sandstone. See St. Peter sandstone.

Peters, E. D., copper deposits reported by. . 37-38

Phelps County, copper in..

Pilot Knob conglomerate, occurrence and character of .

Potosi group, copper in .................. 50

deposition of ...................... 27-28

divisions of ............................ 12,27

occurrence and character of .......... 12,

$16,19-20,25-35$

Potosi limestone, etc. See Elvins formation.

Proctor limestone. See Gasconade limestone.

Rogers, F. M., Slater mir e leased by...... $\quad 42$

Roubidoux formation, copper in......... 46,50 occurrence and character of ........ 12,

$14,16,18,31-33,43,47-48$

Saccharoidal sandstone. See St. Peter sandstone.

St. Elizabeth formation. See Roubidoux formation.
Page.

St. Francis Mountains, location of ........ 10 rocks of ........................ 10-11,21

St. James, copper near ................ 47

St. Peter sandstone, occurence and character of $\ldots \ldots \ldots \ldots \ldots \ldots 12,14-18,35-36$

Ste. Genevieve, copper mines near........ 37

Ste. Genevieve County, copper in ......... 9,50 copper in, production of ............. 10

Ste. Genevieve mines, description of ..... $36-39,50$

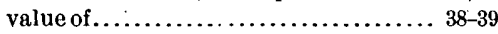

workings of, plate showing........... 36

Saratogan rocks, occurrence and character of ......................... 12

Second Magnesian limestone. See Jefferson City limestone.

Second sandstone. See Roubidoux forma- . tion; La Motte sandstone.

Shannon County, copper in, deposits of .... 40-43 copper in, deposits of, character of...... 42-43

deposits of, map showing.......... 41 mines of, account of ............. 40-47,50 smelting in ......................... 9

Shepard, E. M., on Missouri rocks........ 11-12

Shumard, B. F., on copper............... 9

Slater, Joseph, copper mining by .......... 9,42

Slater mine, description of ............ 43-45, 50 location of ......................... 42 production of ..................... 10,42

Smith, A. F., and Ball, S. H., on Missouri rocks ..................... 12,17

Smith, George, copper discovered by....... ${ }_{42}$

Steiger, George, assay by ............... 49

Sullivan, Mo., copper at:............... 9-10

copper at, shipments of............. 10

smelter at ............................ 47

Sullivan mines, description of $\ldots \ldots \ldots \ldots \ldots$ 47-50

location of .......................... 47

Sutton mine, description of............ 45-46,50

Swallow, G. C., on magnesian series....... 13-14

Swansea mine, opening of ................. 36

Third Magnesian limestone. See Gasconade limestone.

Third sundstone. See Gasconade limestone.

Tyrrell mine, description of .............. 46

Williams, G. K., on copper production..... 10

Winfield limestone. See Jefferson City - limestone.

Winslow, Arthur, on La Motte sandstone .. 222, 39 on Missouri rocks............... 12, 15-16 on Potosi group.................... 26

Ulrich, E. O., work of ................. 9

Yellville group, occurrence and character

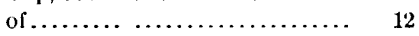

Zinc, occurrence of .................. 10 